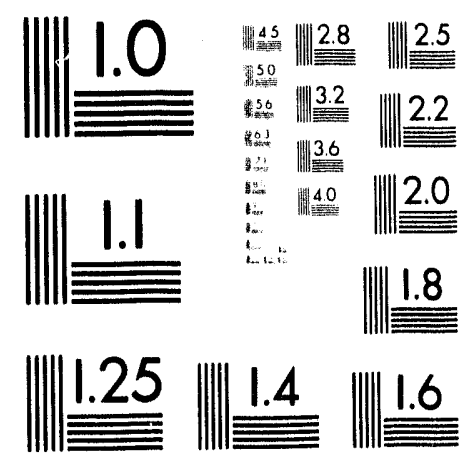



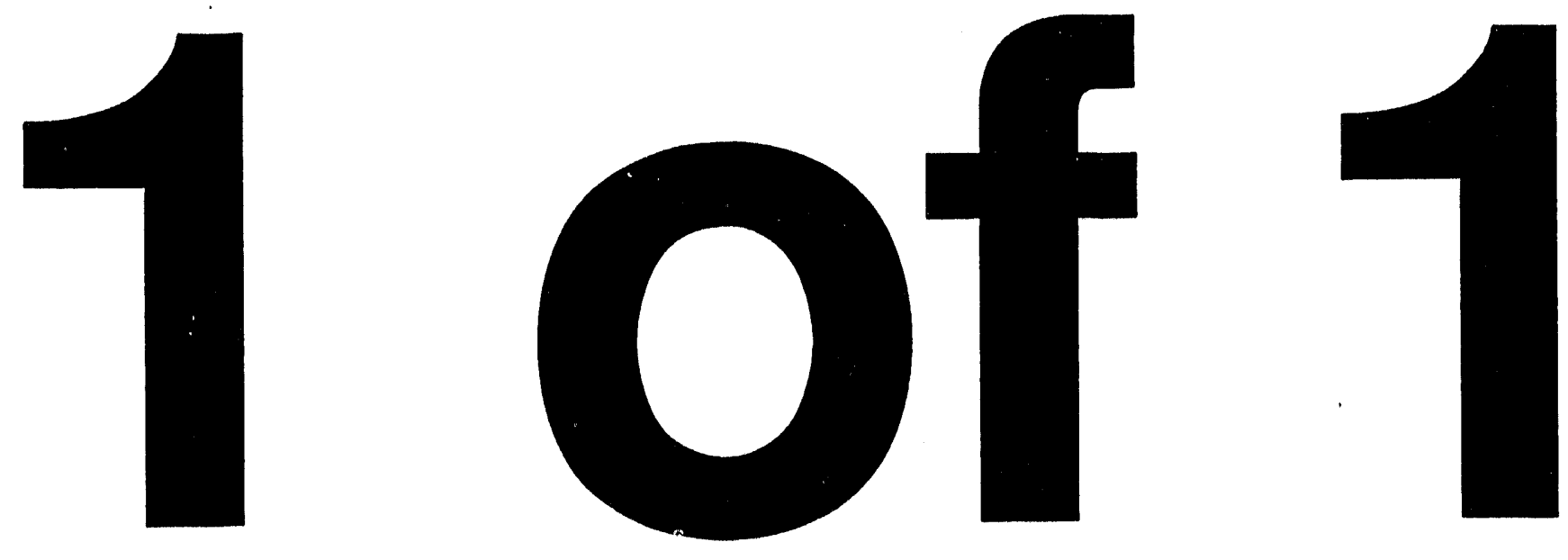


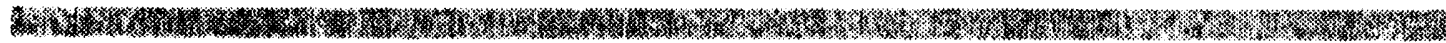

A Compilation of Radionuclide Transfer Factors for the Plant, Meat, Milk, and Aquatic Food Pathways and the Suggested Default Values for the RESRAD Code

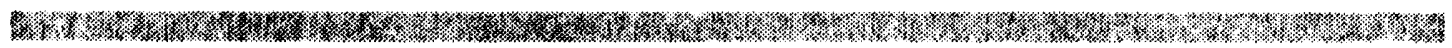

by Y.-Y. Wang, B.M. Biwer, and C. Yu

Environmental Assessment and Information Sciences Division,

Argonne National Laboratory, 9700 South Cass Avenue, Argonne, Illinois 60439

August 1993

Work sponsored by United States Department of Energy, Assistant Secretary for Environment, Safety and Health,

Office of Environmental Guidance

and

Assistant Secretary for Environmental Restoration and Waste Management, Office of Environmental Restoration 


\section{CONTENTS}

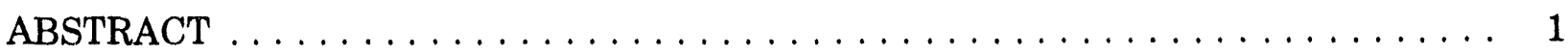

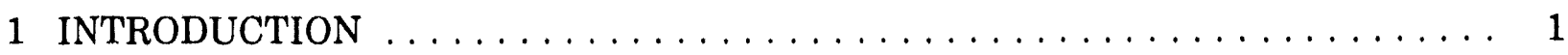

2 DATA COMPILATION AND COMPARISON $\ldots \ldots \ldots \ldots \ldots \ldots \ldots$

2.1 Vegetable/Soil Transfer Factors for Root Uptake . . . . . . . . . . . . . 2

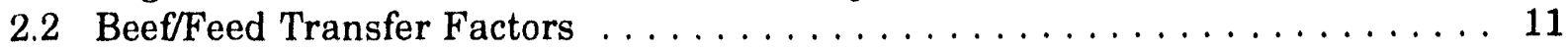

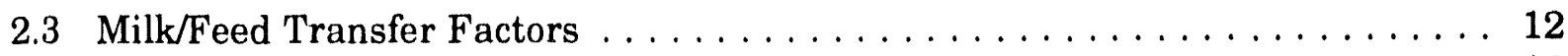

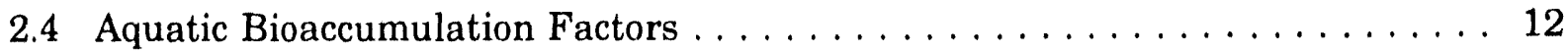

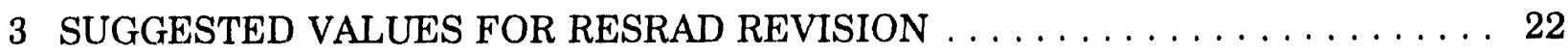

4 SUGGESTIONS FOR FUTURE WORK $\ldots \ldots \ldots \ldots \ldots \ldots \ldots \ldots \ldots \ldots$

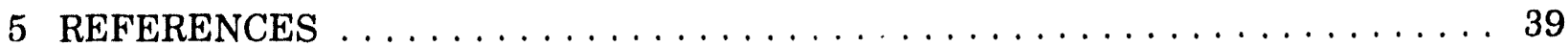

\section{TABLES}

1 Transfer Factors and References Cited in Each Radiological Assessment Report Used as a Source for Data Compilation . . . . . . . . . . . . . 3

2 Dry-to-Wet Weight Conversion Factors for Food Crops and Forage Plants . . . . . 5

3 Descriptions of Food Classes for Human and Animal Food Consumption and Associated Data Sources $\ldots \ldots \ldots \ldots \ldots$

4 Compilation of Vegetable/Soil Transfer Factors for Plant Foods . . . . . . . . . . 7

5 Compilation of Beef/Feed Transfer Factors $\ldots \ldots \ldots \ldots \ldots \ldots$

6 Compilation of Milk/Feed Transfer Factors $\ldots \ldots \ldots \ldots \ldots \ldots \ldots$

7 Compilation of Aquatic Bioaccumulation Factors for Freshwater Fish $\ldots \ldots \ldots$

8 Compilation of Aquatic Bioaccumulation Factors for Crustacea and

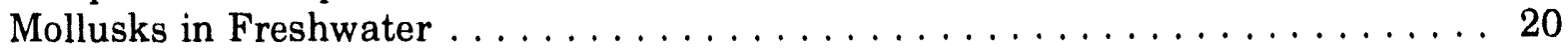

9 Current RESRAD Default Values and Suggested Values for Vegetable/Soil Transfer Factors for Composite Plant Foods . . . . . . . . . . . . . . . . 23

10 Suggested RESRAD Default Values for Specific Plant Foods . . . . . . . . . . 25 


\section{TABLES (Cont.)}

11 Current RESRAD Default Values and Suggested Values for

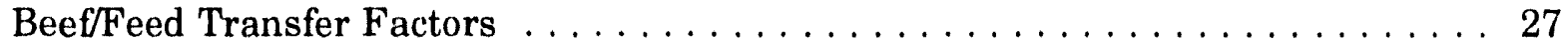

12 Current RESRAD Default Values and Suggested Values for Milk/Feed Transfer Factors . . . . . . . . . . . . . . . . . . . . . . 30

13 Current RESRAD Default Values and Suggested Values for Aquatic Bioaccumulation Factors for Freshwater Fish $\ldots \ldots \ldots \ldots \ldots \ldots$

14 Compilation of Aquatic Bioaccumulation Factors for Crustacea

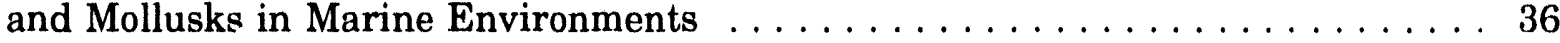




\title{
A COMPILATION OF RADIONUCLIDE TRANSFER FACTORS FOR THE PLANT, MEAT, MILK, AND AQUATIC FOOD PATHWAYS AND THE SUGGESTED DEFAULT VALUES FOR THE RESRAD CODE
}

\author{
by
}

\author{
Y.-Y. Wang, B.M. Biwer, and C. Yu
}

\begin{abstract}
The ongoing development and revision of the RESRAD computer code at Argonne National Laboratory requires update of radionuclide transfer factors for the plant, meat, milk, and aquatic food pathways. Default values for these transfer factors used in published radiological assessment reports are compiled and compared with values used in RESRAD. The differences among the reported default values used in different radiological assessment codes and reports are also discussed. In data comparisons, values used in more recent reports are given more weight because more recent experimental work tends to be conducted under betterdefined laboratory or field conditions. A new default value is suggested for RESRAD if one of the following conditions is met: (1) values used in recent reports are an order of magnitude higher or lower than the default value currently used in RESRAD, or (2) the same default value is used in several recent radiological assessment reports.
\end{abstract}

\section{INTRODUCTION}

The radionuclide transfer factors for the plant, meat, milk, and aquatic food pathways used in the current version of the RESRAD computer code (Gilbert et al. 1989) are derived primarily from a handbook compiled by $\mathrm{Ng}$ et al. (1968). These factors are being updated at Argonne National Laboratory as part of the ongoing RESRAD development and revision effort. In Section 2 of this report, values of transfer factors used in the literature are compiled and compared with default values used in the current version of RESRAD. In Section 3, on the basis of these comparisons, new default values are suggested for future application of RESRAD. 


\section{DATA COMPILATION AND COMPARISON}

Data from several published radiological assessment reports, listed in Table 1, are used as the sources for the transfer factors compiled in this report. The vegetable/soil, beef/feed, milk/feed, and aquatic food bioaccumulation transfer factors are compiled and compared in the following subsections.

\subsection{VEGETABLE/SOIL TRANSFER FACTORS FOR ROOT UPTAKE}

Comparison of vegetable/soil transfer factors for root uptake used in RESRAD with those used in other published radiological assessment models can be difficult because the parameters are generally reported in one of two different formats. In RESRAD (Gilbert et al. 1989), the food transfer coefficient for plants is expressed as the ratio: pCi per gram plant (wet)/pCi per gram soil (dry). In other published radiological assessment reports, the plant/soil concentration ratios have been reported on the basis of either the fresh (wet) weight or the dry weight of the vegetation. Dry-to-wet weight conversion factors must be estimated to make comparison possible. An overall average value of 0.428 for this parameter has been estimated by Baes et al. (1984) by the following processes: (1) calculation of the dry-to-wet weight conversion factors for exposed produce, protected produce, and grains on the basis of relative importance of various nonleafy vegetables in the United States; and (2) calculation of the average dry-towet conversion factor by weighing these calculated values by the relative importance (based on production in kilograms) of each vegetable category in the United States. Baes et al. (1984) caution, however, that unnecessary uncertainty might be introduced into the estimated parameter, and thus the adoption of dry-weight concentration ratios is preferred so as to reduce additional imprecision in parameter estimates.

A similar recommendation has been made by the IAEA (1982). For vegetation consumed by animals, expressing the vegetation biomass on a dry-weight basis is preferred so as to reduce both the large variability associated with the moisture content of fresh vegetation and the difficulties in accurately determining the fresh weight. In addition, animal consumption rates are most frequently reported on a dry-weight basis. On the other hand, for vegetation consumed by humans, it is more convenient to refer to the harvest yield or standing crop biomass on a fresh-weight basis because human consumption is most frequently reported in fresh weight. To aid in converting between the two bases of measurement, representative dry-to-wet weight ratios for food crops and forage plants that have been presented by Baes et al. (1984) and NRC (1983) are summarized in Table 2.

The vegetable/soil transfer factor of a radionuclide varies in a complex manner with soil properties and the geochemical properties of the radionuclide in soil. After entering the transpiration stream, radionuclides may not be uniformly distributed within a plant, but instead tend to concentrate in certain organs (Grogan 1985). Many studies have shown that 

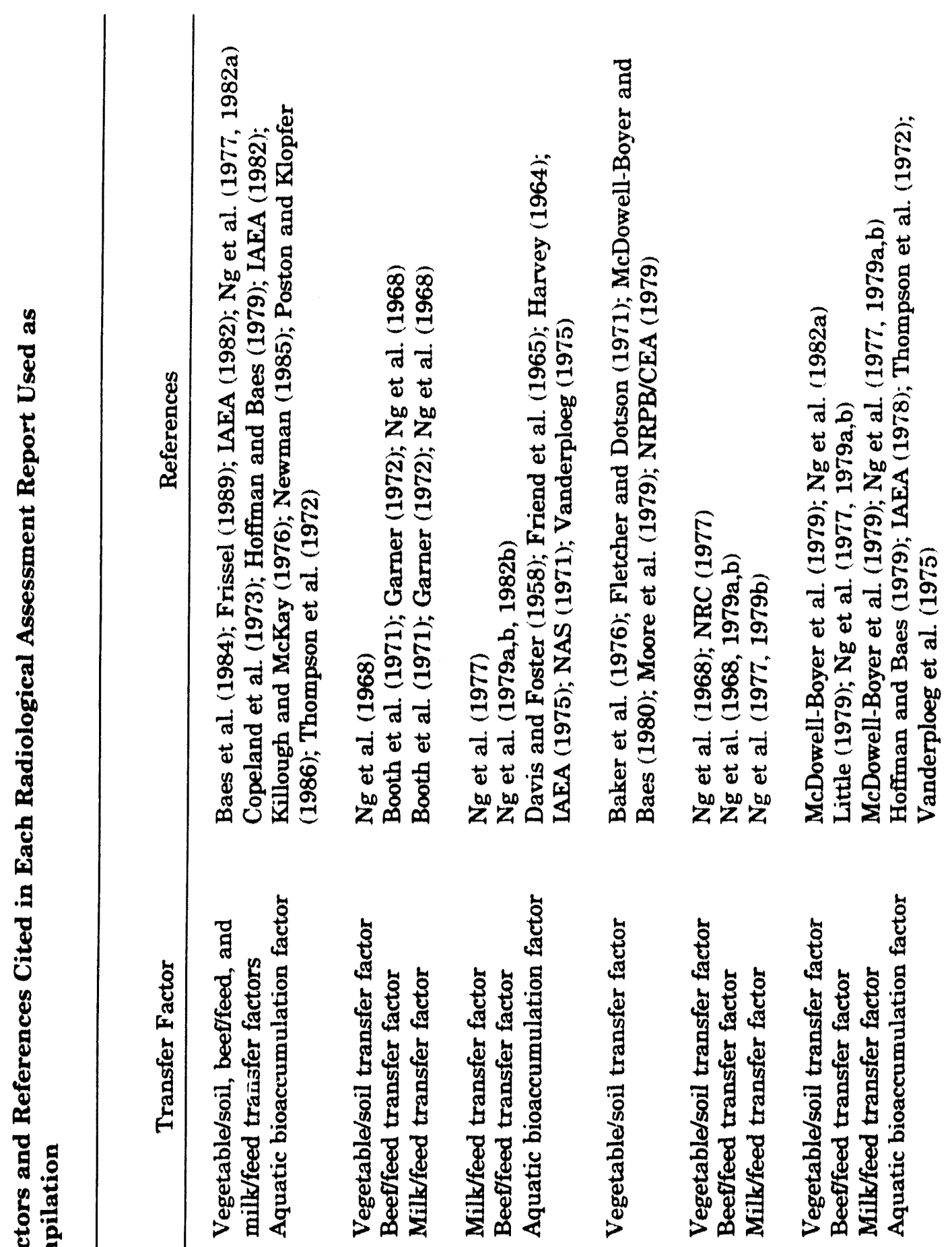

造

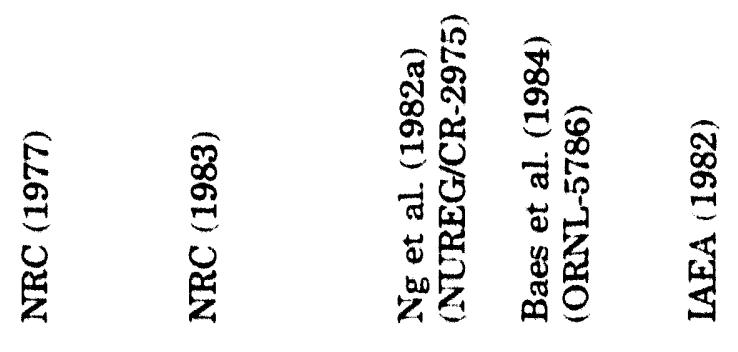




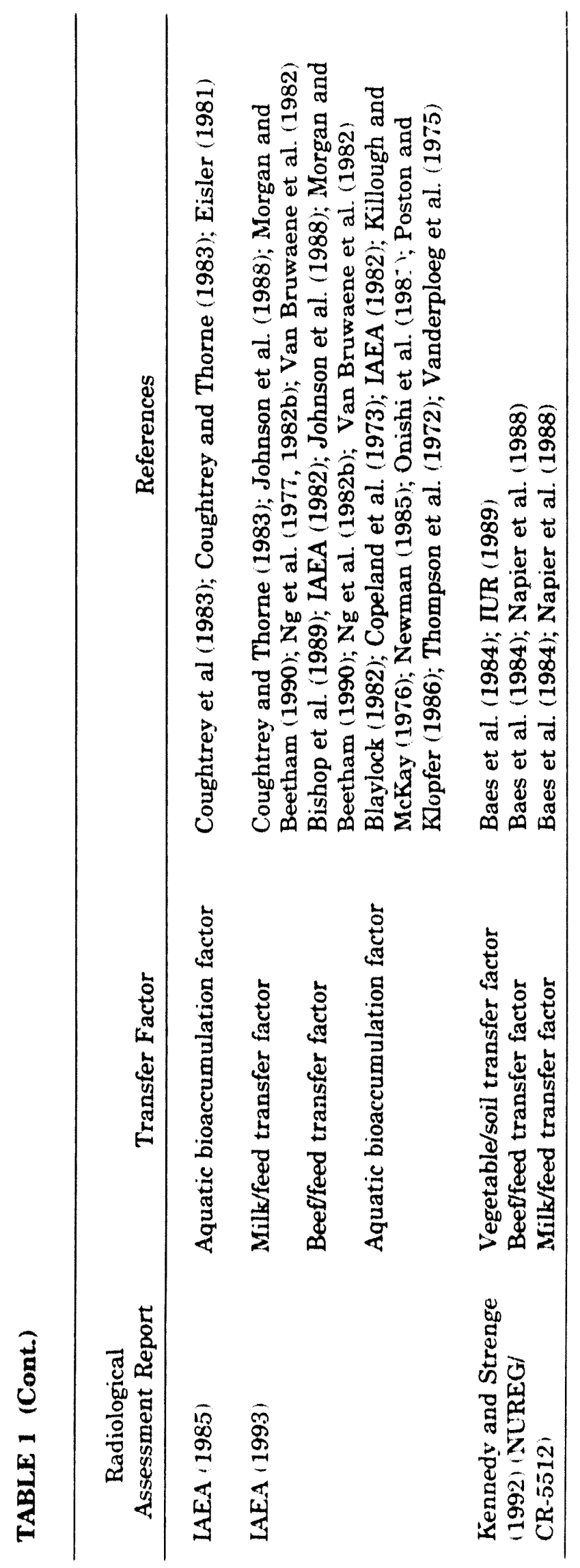


TABLE 2 Dry-to-Wet Weight Conversion Factors for Food

Crops and Forage Plants

\begin{tabular}{|c|c|c|c|c|c|}
\hline Crop & $\begin{array}{c}\text { Baes et al. } \\
(1984)\end{array}$ & $\begin{array}{c}\text { NRC } \\
(1983)\end{array}$ & Crop & $\begin{array}{c}\text { Baes et al. } \\
\quad(1984)\end{array}$ & $\begin{array}{c}\text { NRC } \\
\text { (1983) }\end{array}$ \\
\hline Leafy Vegetables & & & Fruits (Cont.) & & \\
\hline Asparagus & 0.070 & 0.083 & Raspberry & - & 0.175 \\
\hline Cabbage & $-a$ & 0.077 & Cucumber & 0.039 & 0.050 \\
\hline Cauliflower & - & 0.083 & Eggplant & 0.073 & 0.077 \\
\hline Celery & - & 0.063 & Pepper & - & 0.067 \\
\hline Lettuce & - & 0.050 & Pumpkin & - & 0.084 \\
\hline Rhubarb & - & 0.053 & Squash & 0.082 & 0.060 \\
\hline Spinach & - & 0.083 & Tomato & 0.059 & 0.067 \\
\hline Broccoli & - & 0.110 & Grapefruit & 0.112 & 0.116 \\
\hline Brussels sprout & - & 0.147 & Orange & 0.128 & 0.141 \\
\hline Kale & - & 0.125 & Peach & 0.131 & 0.109 \\
\hline \multirow[t]{2}{*}{ Turnip green } & - & 0.100 & Strawberry & 0.101 & 0.101 \\
\hline & & & Cantaloupe & 0.060 & - \\
\hline Root Vegetables & & & Watermelon & 0.079 & . \\
\hline Potato & 0.222 & 0.222 & Lemon & 0.107 & - \\
\hline Sweet potato & 0.315 & 0.294 & & & \\
\hline Yam & - & 0.263 & Grains & & \\
\hline Beet & - & 0.127 & Barley & 0.889 & 0.926 \\
\hline Carrot & 0.118 & 0.118 & Rice &. & 0.877 \\
\hline Onion & 0.125 & 0.116 & Wheat & 0.875 & 0.870 \\
\hline Radish & - & 0.056 & Corn & 0.895 & 0.263 \\
\hline \multirow[t]{2}{*}{ Turnip } & - & 0.085 & & & \\
\hline & & & Forage & & \\
\hline Fruits & & & Alfalfa & - & 0.227 \\
\hline Apple & 0.159 & 0.149 & Clover & - & 0.200 \\
\hline Apricot & $\cdot$ & 0.147 & Grass & - & 0.182 \\
\hline Bunana & - & 0.244 & Silage & - & 0.238 \\
\hline Blackberry & - & 0.156 & & & \\
\hline Blueberry & - & 0.167 & Others & & \\
\hline Cherry & 0.170 & 0.196 & Lima bean & - & 0.322 \\
\hline Fig & - & 0.227 & Pea & 0.257 & 0.169 \\
\hline Pear & 0.173 & 0.167 & Green bean & - & 0.100 \\
\hline Pineapple & - & 0.147 & Chestnut & - & 0.476 \\
\hline Plum & 0.540 & 0.189 & Peanut & 0.920 & 0.943 \\
\hline
\end{tabular}

A No conversion factor is given by the source. 
the vegetable/soil transfer factor also varies with crop type and variety, stage of growth, and plant part, as well as with subsoil characteristics and agriculture practices (Baes et al. 1984; IAEA 1993; $\mathrm{Ng}$ et al. 1982a). Comprehensive data on transfer factors in different crops grown on various soils are available in the literature for relatively few radionuclides. Data for radionuclides for which little or no experimental information exists have been customarily estimated on the basis of the assumption that chemically similar elements act similarly in the soil-plant environment (Baes et al. 1984). Relationships between transfer factors for an element and those for other elements of the same or adjacent periods or groups were established and examined for possible trends. Such trends were extrapolated to the element in question.

In published radiological assessment models, default values for vegetable/soil transfer factors are reported as composite values from various food and feed crops or as separate values for forage vegetation and edible portions of various vegetables and produce. The current version of the RESRAD computer code uses composite values of vegetable/soil transfer tactors. Differences among food crops (such as leafy vegetables, root vegetables, fruits, grain, and forage plants) and consumption groups (such as humans and animals) are not considered. To take any such differences into account, categorization of crop plants into different food classes is required. Four food classes $(k=0,1,2$, and 3$)$ are used in this report to present data collected from different food crops. Food class descriptions and radiological assessment models used as the data source for vegetable/soil transfer factors are listed in Table 3.

Values of vegetable/soil transfer factors for root uptake compiled from published radiological assessment models are listed in Table 4 for the food classes defined in Table 3.

TABLE 3 Descriptions of Food Classes for Human and Animal Food Consumption and Associated Data Sources

\begin{tabular}{|c|c|c|}
\hline Food Class & Class Description & Assessment Models Usod as Data Sources \\
\hline$k=0$ & Composite & $\begin{array}{l}\text { IAEA (1982); NCRP (1991); Ng et al. (1982a); } \\
\text { NRC (1977) }\end{array}$ \\
\hline$k=1$ & $\begin{array}{l}\text { Root vegetables, fruits, and } \\
\text { grain for human consumption }\end{array}$ & $\begin{array}{l}\text { Baes et al (1984); IAEA (1993); Kennedy and } \\
\text { Strenge (1992); Napier ot al. (1988); Ng et al. } \\
\text { (1982a) }\end{array}$ \\
\hline$k=2$ & $\begin{array}{l}\text { Leafy vegetables for human } \\
\text { consumption }\end{array}$ & $\begin{array}{l}\text { Baes ot al. (1984); IAEA (1993); Kennedy and } \\
\text { Strenge (1992); Napier et al. (1988); } \mathrm{Ng} \text { et al. } \\
\text { (1982a) }\end{array}$ \\
\hline$k=3$ & $\begin{array}{l}\text { Forage plants for pasture } \\
\text { vegetation and other animal } \\
\text { foeds }\end{array}$ & $\begin{array}{l}\text { IAEA (1982, 1993); NCRP (1991); Ng et al } \\
(1982 a)\end{array}$ \\
\hline
\end{tabular}




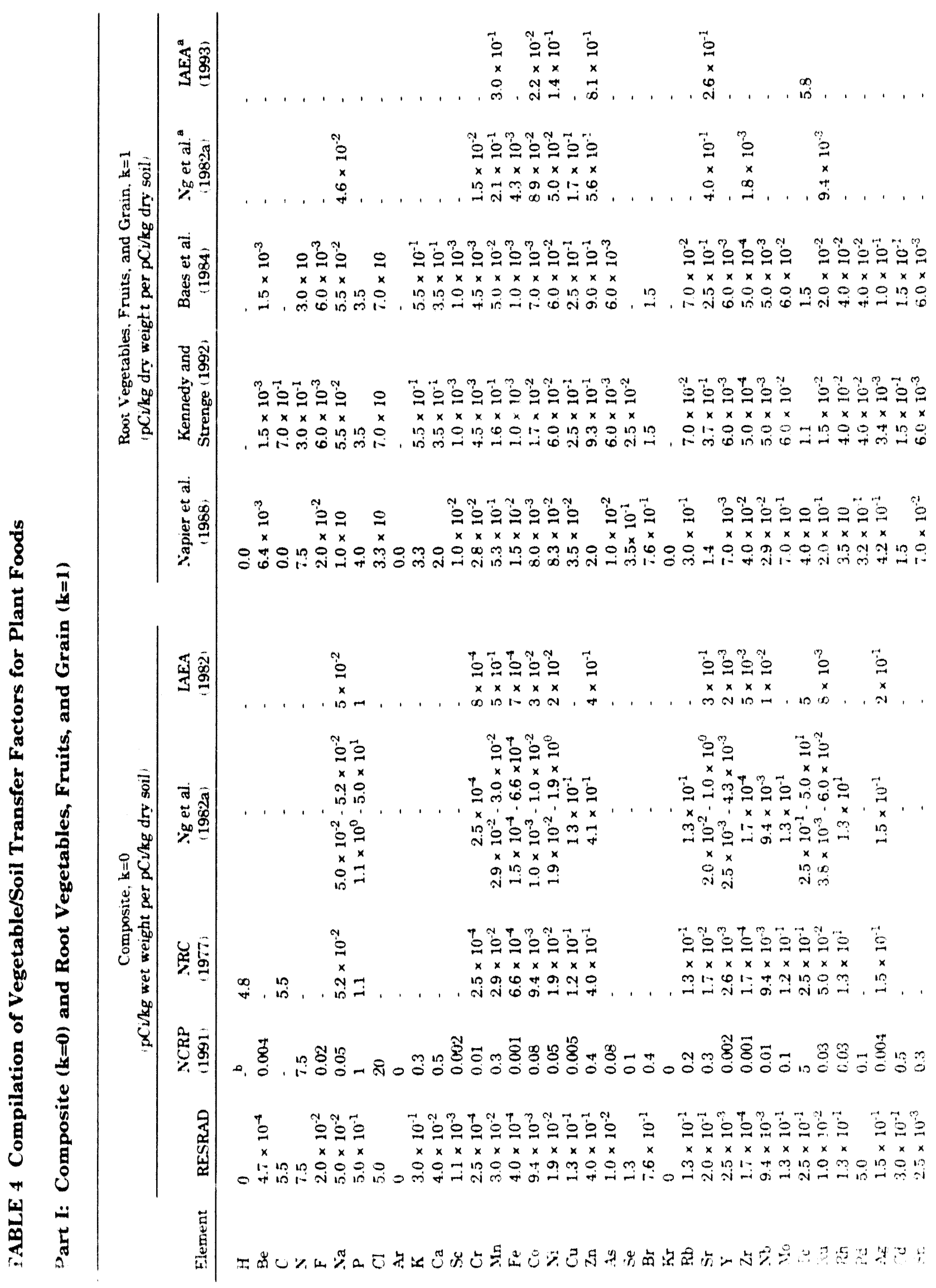




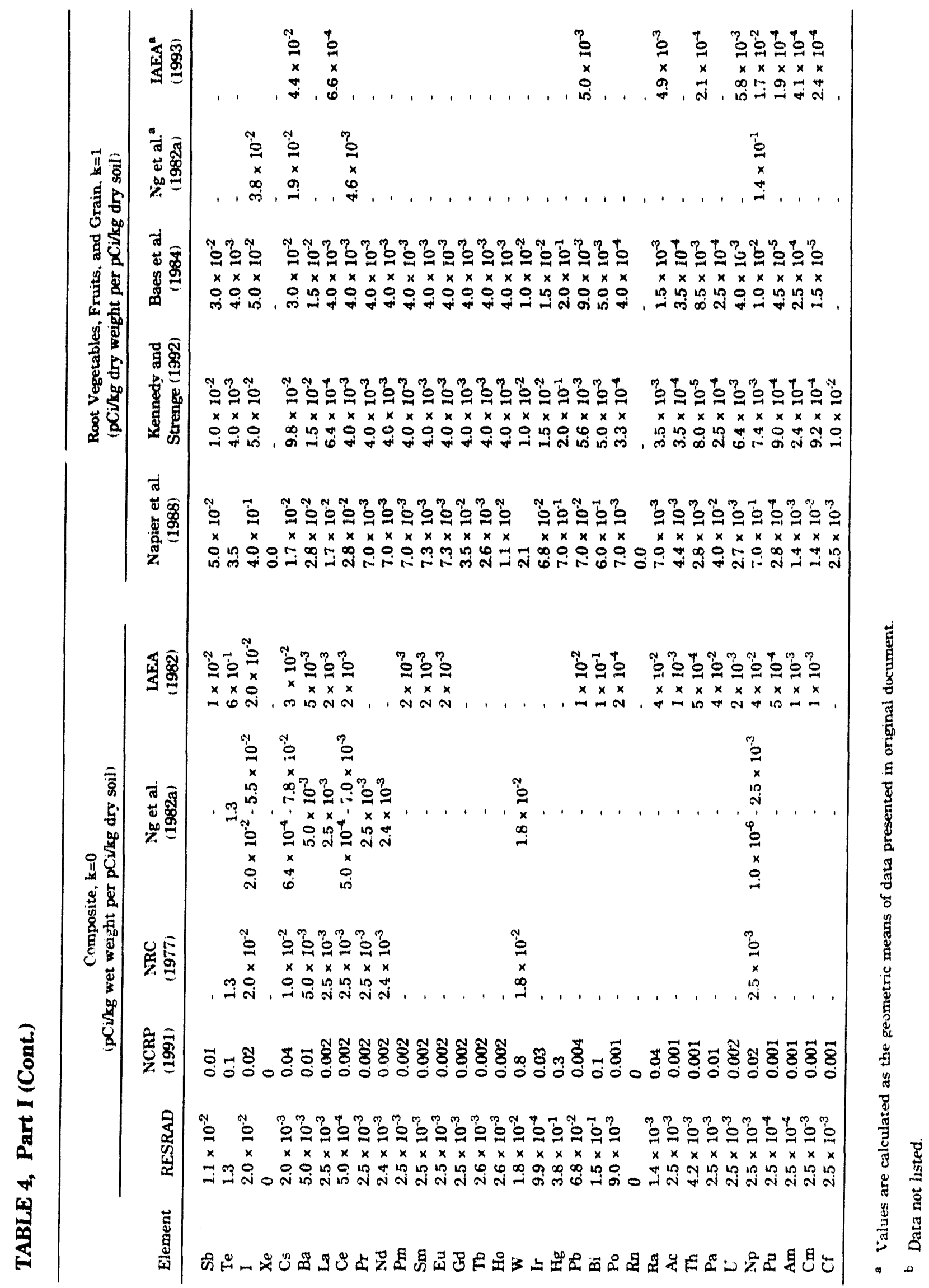




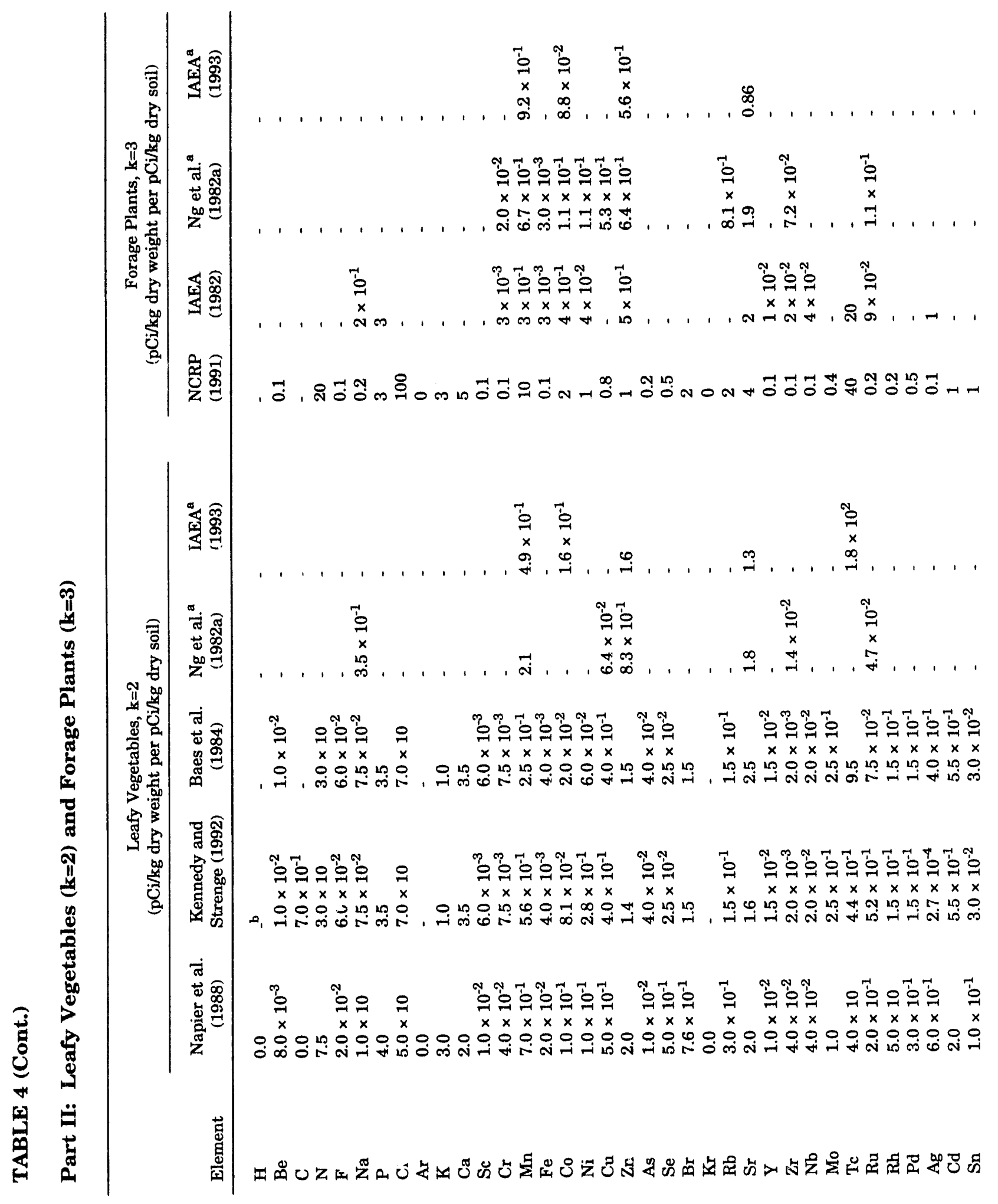




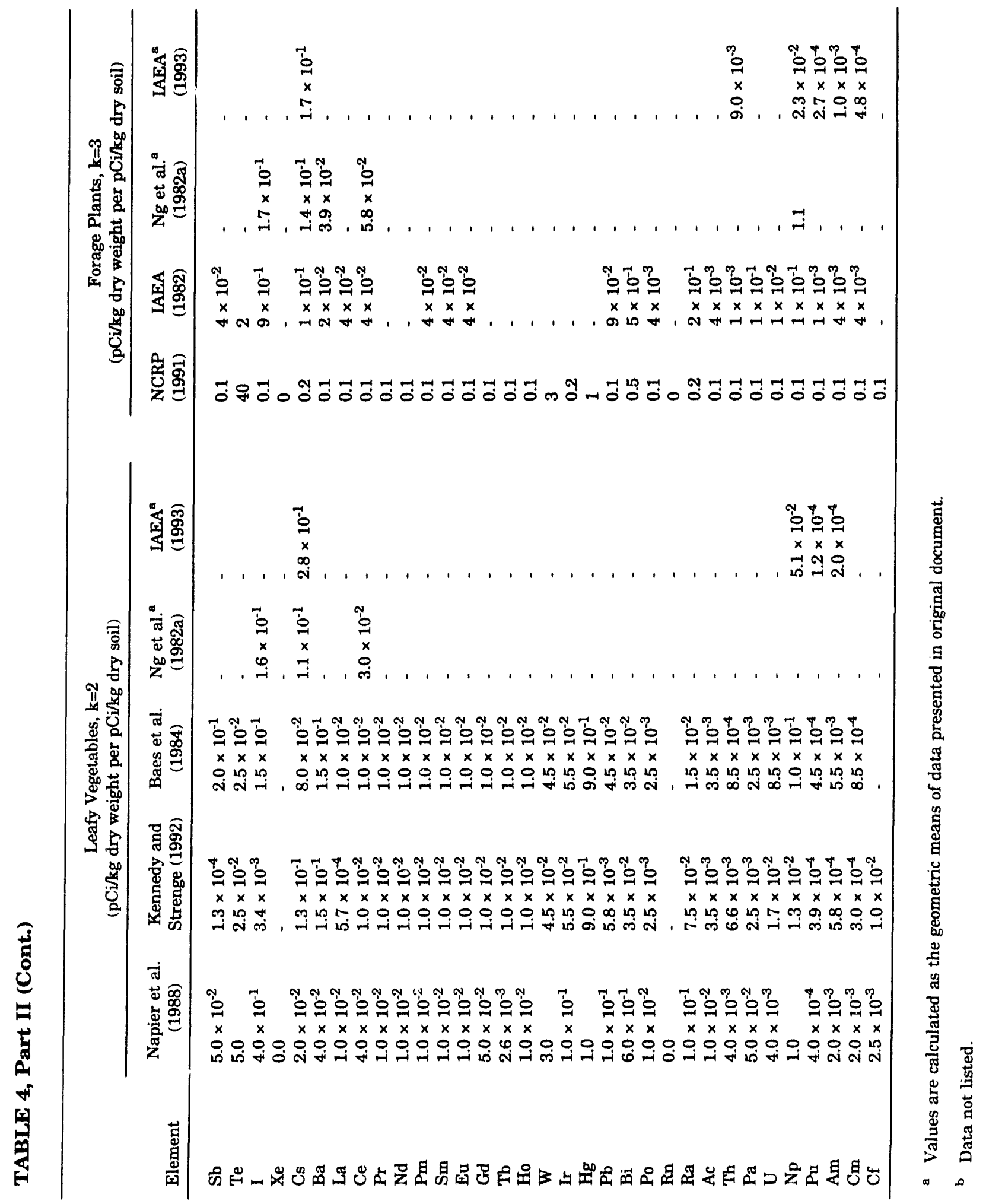


The data are intended to reflect only uptake of radionuclides from plant roots and to exclude the effects of deposition of radionuclides on plant surfaces following resuspension from soil. Comparison of these data is subjective, depending on the number of references available for an element. When many references are available for an element, data comparison can be conducted with reasonable confidence to suggest an appropriate value for future use.

In comparing data, we do not consider a twofold or threefold difference between default values in published reports and those used in RESRAD to be significant. When the difference is greater than an order of magnitude, the values from more recent reports are recommended for use in RESRAD (Section 3). This procedure is based on the assumption that the more recent experimental work has been conducted under better-defined laboratory or field conditions. In addition, a new default value is suggested for RESRAD when the new value, regardless of the magnitude of the difference, is used in several other reports that are based on independent work.

\subsection{BEEF/FEED TRANSFER FACTORS}

A beef/feed transfer factor represents the fraction of the daily intake of a radionuclide by beef cattle that is transferred to and remains in $1 \mathrm{~kg}$ of meat at equilibrium or at the time of slaughter. It is reported that this transfer factor is perhaps the least well documented in the literature because of the obvious practical difficulty - the need to sacrifice the meat-producing animals to collect the required experimental data (IAEA 1982).

For many elements and/or radionuclides, the beef/feed transfer factor is derived from other sources, such as stable element concentrations in feed and animal tissues, extrapolations from single-dose tracer experiments, and comparison of elemental concentrations in associatec or unassociated meat, or milk, and feed ( $\mathrm{Ng}$ et al. 1982b). Some of the difficulties in deriving the beef/feed transfer factor include the following:

- The need for equilibrium - With a few exceptions, the time required for a radionuclide to reach equilibrium in many animal products (e.g., beef) is so long that few experiments can be conducted sufficiently long to approach equilibrium conditions (IAEA 1993). Hence, a transfer factor derived from comparatively short experiments will underestimate the equilibrium transfer factor.

- Effect of chemical and physical forms of diet and composition - The availability of a radionuclide for gut uptake differs markedly, depending on the chemical and physical forms of the radionuclide and on the constituents of the diet (Beresford et al. 1989; Howard et al. 1989; Johnson et al. 1968). Higher radionuclide concentrations are often found in tissues other than muscle, particularly liver (e.g., for $\mathrm{Pu}, \mathrm{Am}, \mathrm{Co}, \mathrm{Ag}$, $\mathrm{Ru}$ ) and bone (e.g., Pu, Am) (IAEA 1993). Radionuclide transfer models often underestimate soil adhesion on vegetation ingested by animals. The extent of soil ingestion will be influenced by the species of aninal, 
season, soil type, stocking rates, and pasture management. Consequently, values for soil ingestion will be highly site specific.

- Influence of age - The intake of radionuclides by an animal is dependent on the animal's species, mass, age, and growth rate, as well as on the digestibility of the feed. Young animals often have enhanced gut uptake and, hence, higher transfer coefficients than adults. Few available transfer coefficient data take these factors into account.

Published radiological assessments used for comparison of beef/feed transfer factors are Baes et al. (1984), IAEA (1982, 1993), Kennedy and Strenge (1992), Napier et al. (1988), NCRP (1991), Ng et al. (1982b), and NRC (1977, 1983). Table 5 lists default values of beef/feed transfer factors compiled from these sources. The same criteria used to compare plant uptake transfer factors were applied.

\subsection{MILK/FEED TRANSFER FACTORS}

A milk/feed transfer factor for milk cows is expressed as the fraction of the daily elemental intake in feed that is transferred to a kilogram of milk. $\mathrm{Ng}$ et al. (1977) report that radionuclide concentrations in animal food products depend on the relationship between intake, turnover in animal tissue, and excretion. The biological availability of a radionuclide in feed for uptake by dairy cattle depends on the physical and chemical forms of that radionuclide. In addition, the secretion of isotopes in milk is influenced by many factors besides physical and chemical states. For example, breed of dairy cow, age, nutritional status, stage of lactation, and feed and management practices are some of the important parameters that must be considered.

Reports reviewed for compilation and comparison of milk/feed transfer factors are Baes et al. (1984), IAEA (1982, 1993), Kennedy and Strenge (1992), Napier et al. (1988), NCRP (1991), and NRC $(1977,1983)$. The milk/feed transfer factors from these sources are compiled in Table 6 . The criteria used for comparing the plant uptake transfer factors were applied.

\subsection{AQUATIC BIOACCUMULATION FACTORS}

A bioaccumulation factor is used to calculate the transfer of a radionuclide from contaminated water through various trophic levels of aquatic foodstuffs consumed by humans. The factor is normally expressed as the ratio of radioactivity in animal tissue to that in water at equilibrium conditions $(\mathrm{Bq} / \mathrm{kg}$ wet or dry weight organism per $\mathrm{Bq} / \mathrm{kg}$ or $\mathrm{L}$ water).

The physicochemical form of the radionuclide is generally more important in aquatic ecosystems than in terrestrial ecosystems. In terrestrial ecosystems, most of the food products are produced in situations where most of the factors can be controlled. In aquatic 


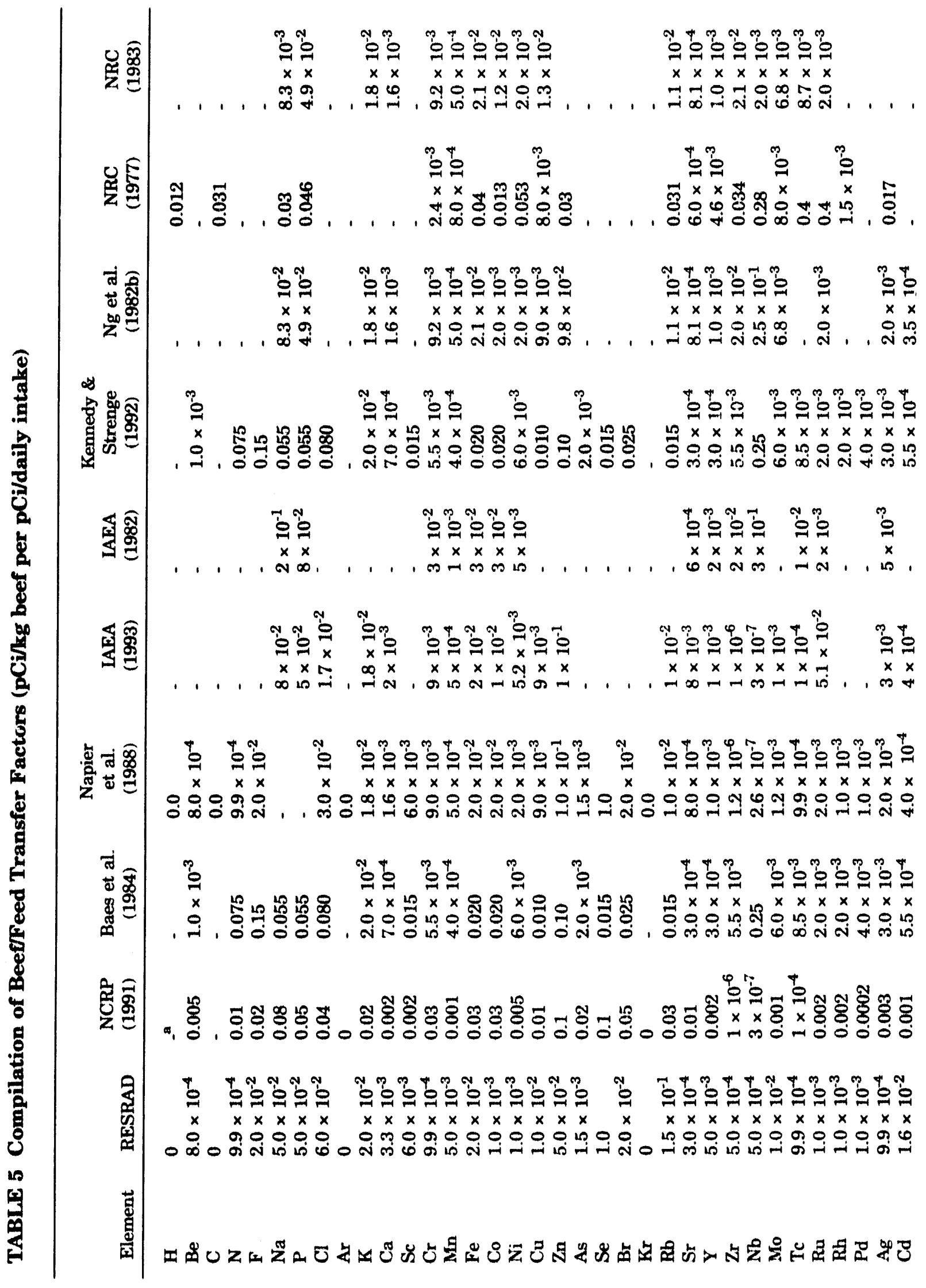




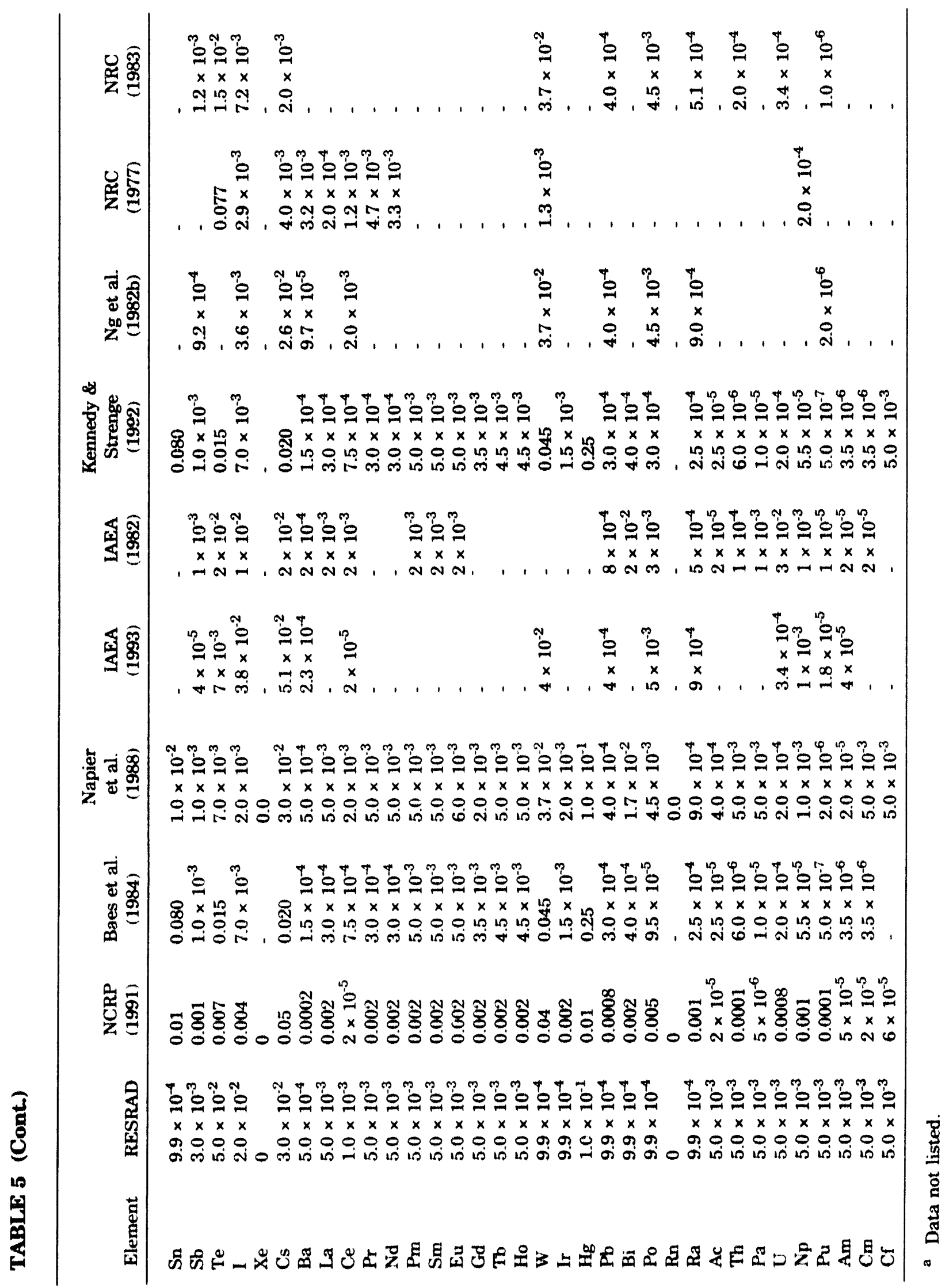




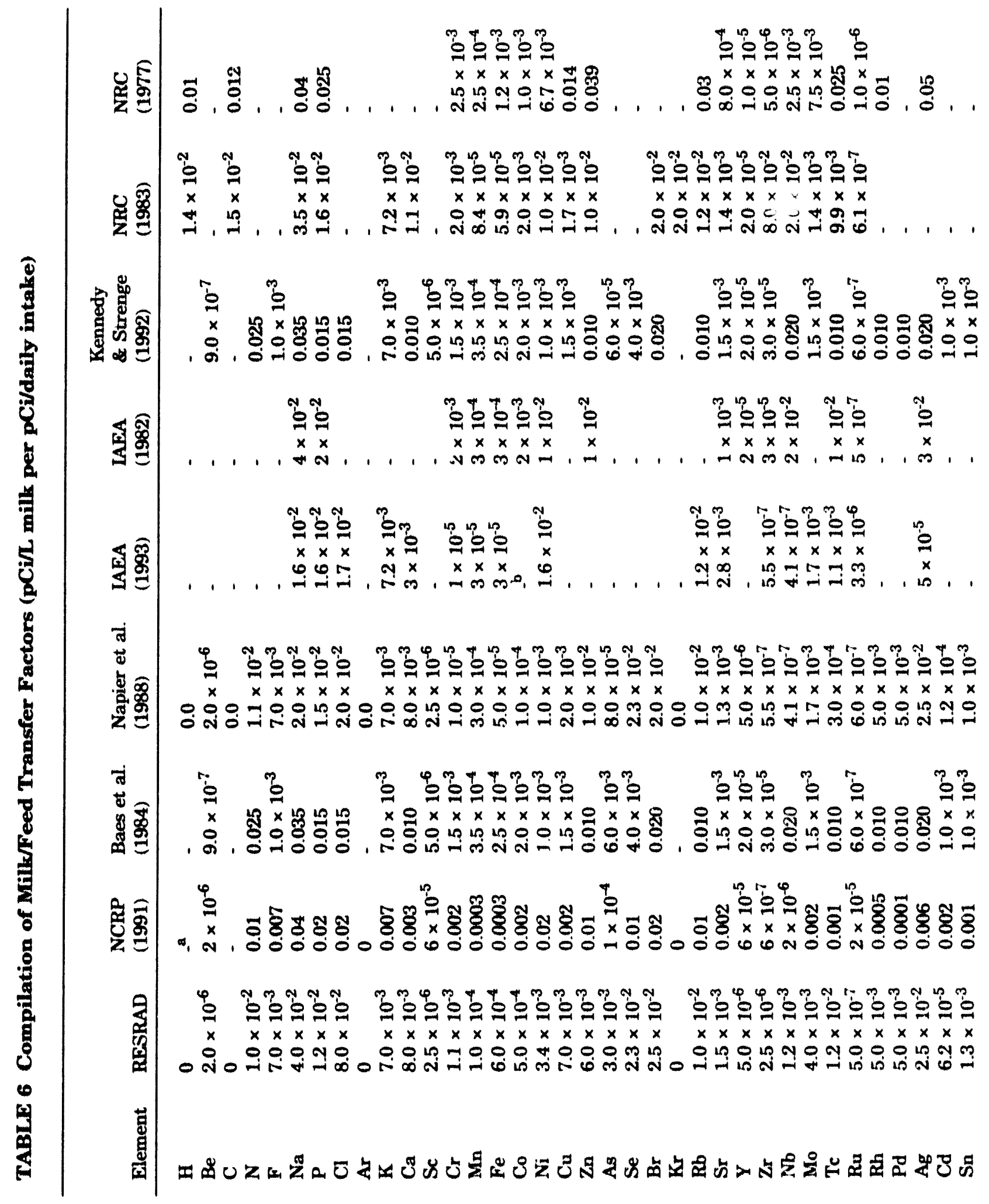




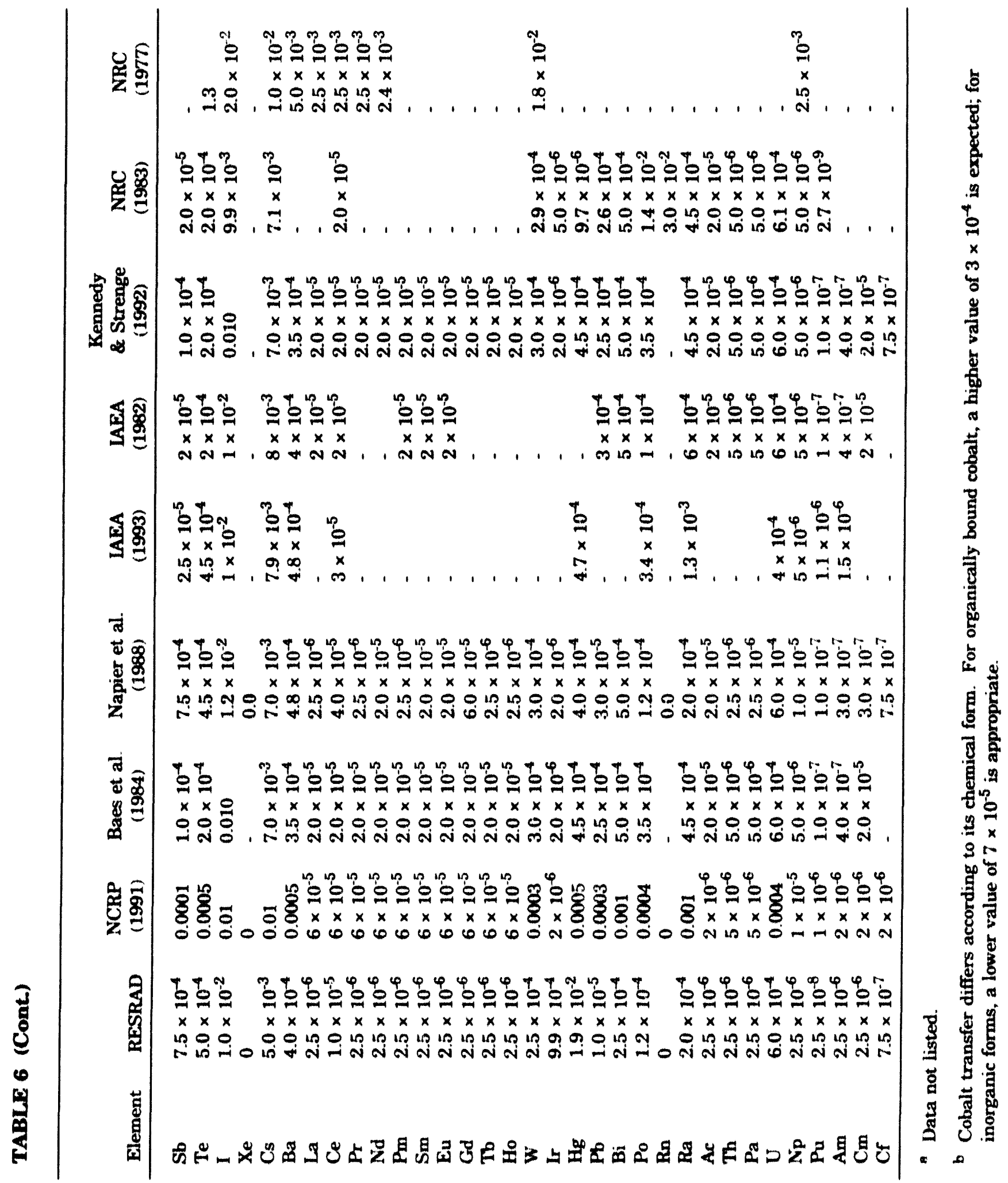


and marine environments, numerous species in the food chain are mobile and can move over considerable distances. Therefore, the concentration of a radionuclide can change much faster with time in aquatic ecosystems than in terrestrial systems, and an equilibrium condition is less likely to be achieved in the former. A radionuclide may exist in water in a truly dissolved state or in an undissolved state as a colloid or sorbed to particulate matter. Reactions between radionuclide and chemical species present in the water determine the biological availability of a radionuclide for uptake in aquatic environments. A dissolved raciionuclide might precipitate out of solution and become less available for uptake if the concentrations of ligands in the water system are sufficiently high that the corresponding solubility product is exceeded. A radionuclide that is adsorbed to particulate matter might dissolve and become available for uptake if the concentrations of ligands and stable isotopes of the radionuclide are such that the solubility product is not exceeded.

The physiological status of fish also plays an important role in their uptake of radionuclides. Young, rapidly growing fish may accumulate highor levels of biologically active radionuclides than fish in a stationary growth period. The osmoregulatory problem faced by freshwater fish and marine fish also determines the difference in the route of radionuclide uptake (Poston and Klopfer 1986). In seawater, the salt concentration is high, and marine fish drink large amounts of water and expend considerable energy to excrete walt against a concentration gradient. In freshwater, fish rotain salt and excrete a large amount of water. Therefore, radionuclides found in the water column, either as dissolved species or sorbed to particulate matter, are more prone to gastrointestinal (Gll absorption in marine species than in freshwater species (Poston and Klopfer 1986).

In the literature, bionccumulation factors are derived by a number of methods, and the reported values vary widely. Historically, radionctivity in animal tissue is estimnted on the basis of ash weight, dry weight, wet weight, whole body burdens, and/or muscle tissue. Radionctivity in water is estimated on the basis of filtered or unfiltered water. Wet weight to dry weight and dry weight to ash weight ratios can vary as a function of the age, size, and species of fish. To make comparisons possible, Poston and Klopfer (1986) listed the values summarized by Vinogradov (1953) for conversion as follows: ash weights ranged from 0.11 to $6.82 \%$, with most in the range of $1.2 \%$; water content ranged from 52.78 to $89.94 \%$; and dry weights ranged from 20 to $40 \%$. For radionuclides that partition into solublo and particulate phases, the degree of partitioning must be considered. A high transfor factor will be obtained if the radionctivity of the soluble (filtrate) fraction is measured. For instince, if $1 \%$ of a radionuclide is present as a soluble species, and the rest is in the solid phase, the transfer factor for a filtered water sumple would be estimated to bo 100 times greater than the factor for an unfiltered water sample (Poston and Kolopfer 1986).

Published radiological assessments used for comparison of bionccumulation transfor through the freshwater pathway are IAFA (1982, 1993), Kennedy and Strenge (1992), NCRP (1991), NRC (1977, 1983), and 'Thompson ot al. (1972). Vulues for freshwater fish compiled from these reports are listed in Table 7. Aquatic bioaccumulation factors for crustacen and mollusks in freshwater, presented in NRC (1983), are listed in Table 8 . The crituria used for comparing plant uptake transfer factors were applied. 


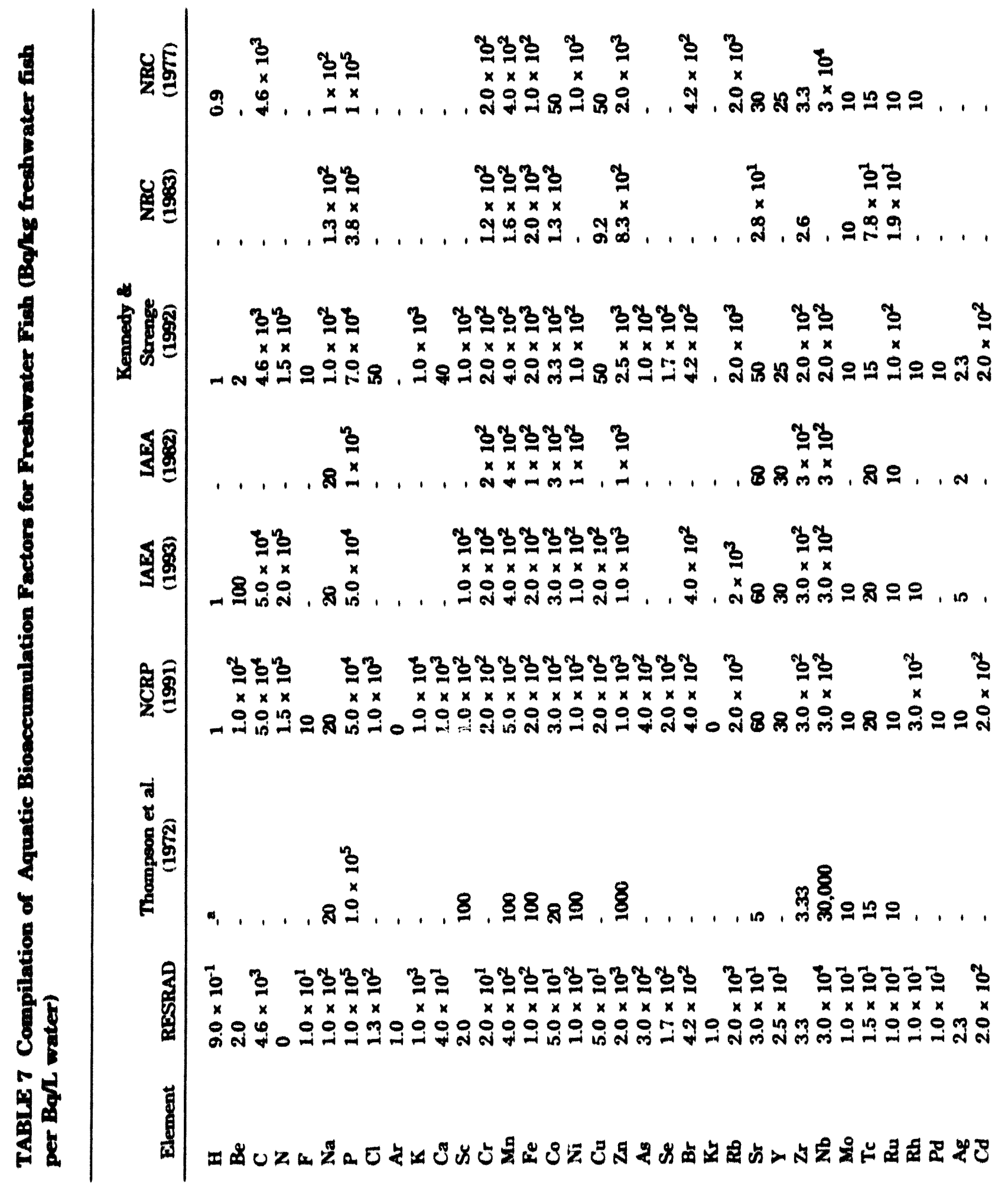




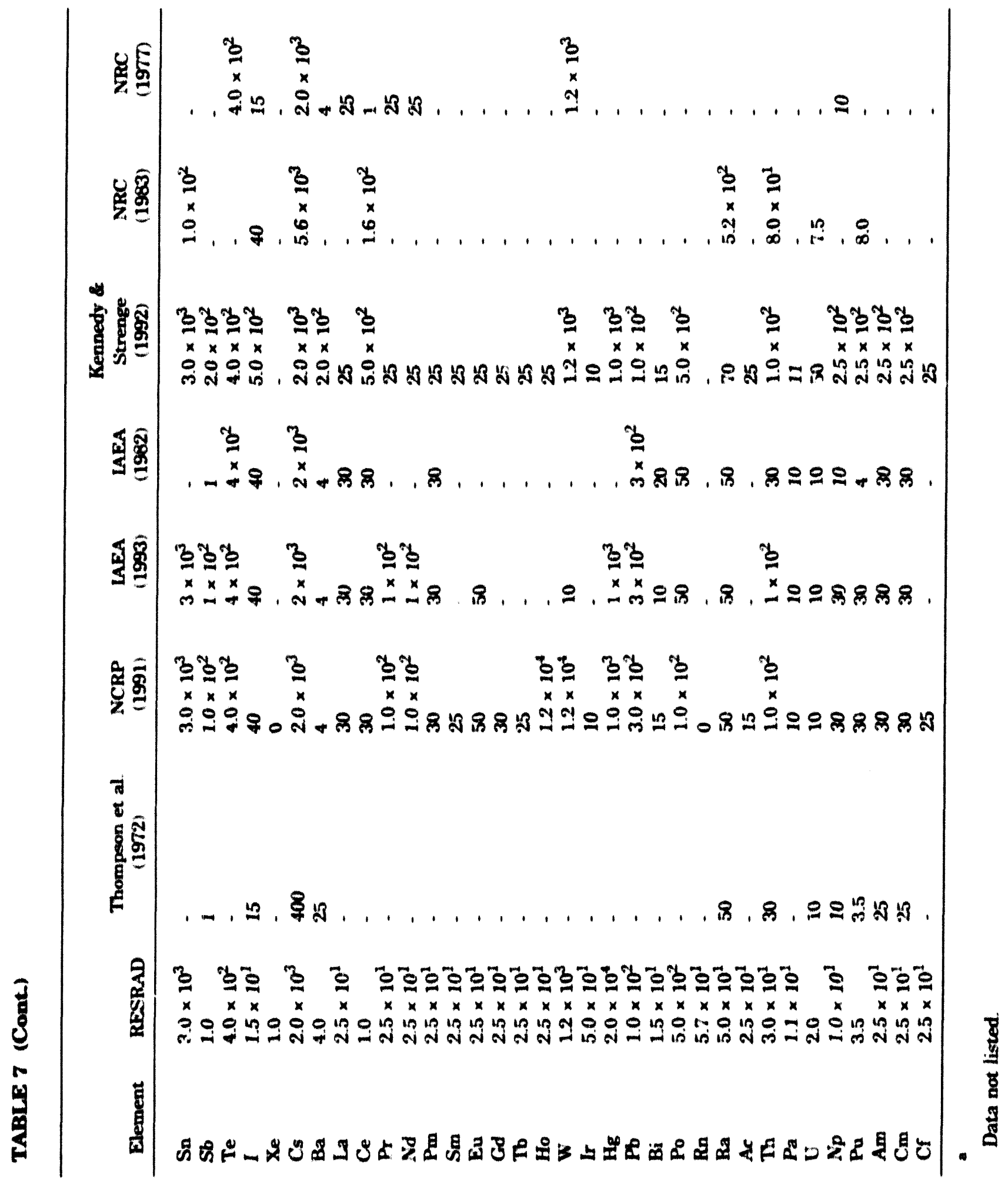




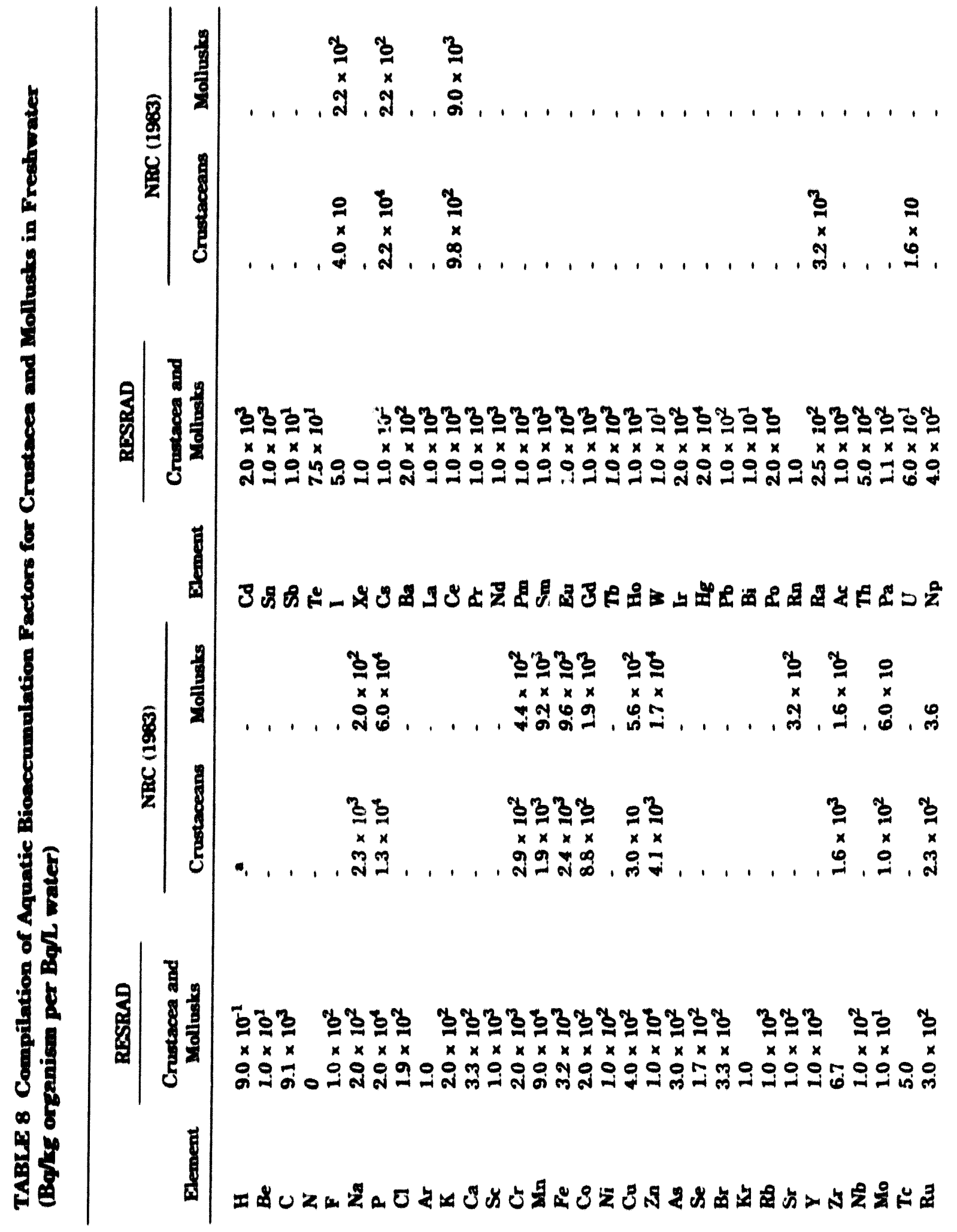




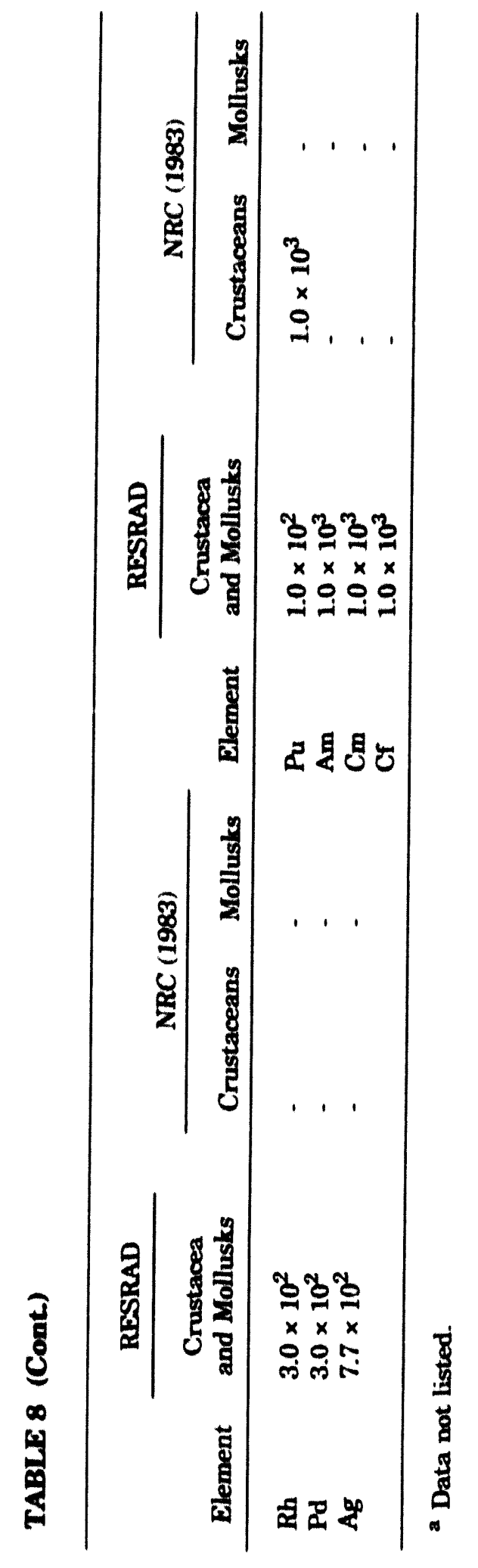




\section{SUGGESTED VALUES FOR RESRAD REVISION}

Summary tables of current and suggested elemental transfer factors for vegetable/soil, beef/feed, milk/feed, and aquatic food bioaccumulation pathways are presented in this section. For future application of RESRAD, suggested default values of vegetable/soil transfer factors for root uptake are presented in Tables 9 and 10. suggested default values of beef/feed and milk/feed transfer factors are presented in Tables 11 and 12, respectively. Suggested default values of aquatic bioaccumulation factors for freshwater fish are presented in Table 13. Each table lists the current value, the suggested value, the change (Isuggested value - default value]/[default value]), and the assessment models on which the suggested changes are based.

\section{SUGGESTIONS FOR FUTURE WORK}

The aquatic bioaccumulation factors used in RESRAD for pathways involving crustacea and mollusks in freshwater are listed in Table D.5 of Gilbert et al. (1989) and are compiled with data reported from NRC (1983) in Table 8. As indicated by the IAEA (1982, 1993), freshwater mollusks and crustacea are minor components of the human food chain. Default values for bioaccumulation factors for freshwater mollusks and crustacea are lacking in most radiological reports reviewed. To provide an overview of possible values of transfer factors for these species, bioaccumulation factors for mollusks and crustacea in marine are listed in Table 14 for future use. Appropriate bioaccumulation factors for freshwater mollusks and crustacea are not suggested in this report because the NRC (1983) report is the only source for data comparison. Update of RESRAD bioaccumulation factors for mollusks and crustacea is recommended for future work. 
TABLE 9 Current RESRAD Default Values and Suggested Values for Vegetable/Soil Transfer Factors for Composite Plant Foods (k=0) (pCi/kg wet weight per pCi/kg dry soil)

\begin{tabular}{|c|c|c|c|c|}
\hline Element & $\begin{array}{c}\text { Current } \\
\text { Default Value }\end{array}$ & $\begin{array}{l}\text { Suggested } \\
\text { Value }\end{array}$ & Change $^{a}$ & $\begin{array}{c}\text { Radiological Assessment } \\
\text { Model Source }\end{array}$ \\
\hline $\mathrm{H}$ & 0 & 4.8 & $-b$ & NRC (1977) \\
\hline $\mathrm{Be}$ & $4.7 \times 10^{-4}$ & $4.0 \times 10^{-3}$ & 7.5 & NCRP (1991) \\
\hline $\mathrm{C}$ & 5.5 & NC & $\mathrm{NC}^{\mathrm{c}}$ & NRC (1977) \\
\hline $\mathbf{N}$ & 7.5 & NC & $\mathrm{NC}$ & NCRP (1991) \\
\hline $\mathrm{F}$ & $2.0 \times 10^{-2}$ & $\mathrm{NC}$ & $\mathrm{NC}$ & NCRP (1991) \\
\hline $\mathrm{Na}$ & $5.0 \times 10^{-2}$ & NC & NC & IAEA (1982); NCRP (1991) \\
\hline $\mathrm{P}$ & $5.0 \times 10^{-1}$ & 1 & 1.0 & IAEA (1982); NCRP (1991) \\
\hline $\mathrm{Cl}$ & 5.0 & 20 & 3.0 & NCRP (1991) \\
\hline $\mathrm{Ar}$ & 0 & NC & $\mathrm{NC}$ & NCRP (1991) \\
\hline $\mathrm{K}$ & $3.0 \times 10^{.1}$ & NC & $\mathrm{NC}$ & NCRP (1991) \\
\hline $\mathrm{Ca}$ & $4.0 \times 10^{-2}$ & $5.0 \times 10^{-1}$ & 11.5 & NCRP (1991) \\
\hline $\mathrm{Sc}$ & $1.1 \times 10^{-3}$ & $2.0 \times 10^{-3}$ & 0.82 & NCRP $(1991)$ \\
\hline $\mathrm{Cr}$ & $2.5 \times 10^{-4}$ & NC & NC & Ng et al. (1982a); NRC (1977) \\
\hline $\mathrm{Mn}$ & $3.0 \times 10^{-2}$ & $3.0 \times 10^{-1}$ & 9.0 & NCRP (1991) \\
\hline $\mathrm{Fe}$ & $4.0 \times 10^{-4}$ & $1.0 \times 10^{-3}$ & 1.5 & NCRP (1991) \\
\hline Co & $9.4 \times 10^{-3}$ & $8.0 \times 10^{-2}$ & 7.5 & NCRP (1991) \\
\hline $\mathrm{Ni}$ & $1.9 \times 10^{-2}$ & $5.0 \times 10^{-2}$ & 1.6 & NCRP (1991) \\
\hline $\mathrm{Cu}$ & $1.3 \times 10^{-1}$ & NC & NC & $\mathrm{Ng}$ et al. (1982a) \\
\hline $\mathrm{Zn}$ & $4.0 \times 10^{-1}$ & NC & NC & $\begin{array}{l}\text { IAEA (1982); NCRP (1991); Ng } \\
\text { et al. (1982a); NRC (1977) }\end{array}$ \\
\hline As & $1.0 \times 10^{-2}$ & $8.0 \times 10^{-2}$ & 7.0 & NCRP (1991) \\
\hline Se & 1.3 & $1.0 \times 10^{-1}$ & -0.92 & NCRP (1991) \\
\hline $\mathrm{Br}$ & $7.6 \times 10^{-1}$ & $\mathrm{NC}$ & NC & \\
\hline $\mathbf{K r}$ & 0 & NC & NC & NCRP (1991) \\
\hline $\mathrm{Rb}$ & $1.3 \times 10^{-1}$ & NC & NC & Ng et al. (1982a); NRC (1977) \\
\hline $\mathrm{Sr}$ & $2.0 \times 10^{-1}$ & $3.0 \times 10^{-1}$ & 0.50 & IAEA (1982); NCRP (1991) \\
\hline $\mathbf{Y}$ & $2.5 \times 10^{-3}$ & NC & NC & \\
\hline $\mathbf{Z} \mathbf{r}$ & $1.7 \times 10^{-4}$ & $1.0 \times 10^{-3}$ & 4.9 & NCRP (1991) \\
\hline $\mathrm{Nb}$ & $9.4 \times 10^{-3}$ & $1.0 \times 10^{-2}$ & 0.06 & LAEA (1982); NCRP (1991) \\
\hline Mo & $1.3 \times 10^{-1}$ & $\mathrm{NC}$ & NC & $\mathrm{Ng}$ et al. (1982a); NRC (1977) \\
\hline $\mathrm{Tc}$ & $2.5 \times 10^{-1}$ & 5 & 19 & IAEA (1982); NCRP (1991) \\
\hline $\mathrm{Ru}$ & $1.0 \times 10^{-2}$ & $3.0 \times 10^{-2}$ & 2.0 & NCRP (1991) \\
\hline $\mathrm{Rh}$ & $1.3 \times 10^{-1}$ & NC & NC & Ng et al. (1982a); NRC (1977) \\
\hline $\mathrm{Pd}$ & 5.0 & $1.0 \times 10^{-1}$ & -0.98 & NCRP (1991) \\
\hline $\mathrm{Ag}$ & $1.5 \times 10^{-1}$ & $\mathrm{NC}$ & $\mathrm{NC}$ & Ng et al. (1982a); NRC (1977) \\
\hline $\mathrm{Cd}$ & $3.0 \times 10^{-1}$ & $\mathrm{NC}$ & $\mathrm{NC}$ & \\
\hline $\mathrm{Sn}$ & $2.5 \times 10^{-3}$ & $\mathrm{NC}$ & NC & \\
\hline $\mathrm{Sb}$ & $1.1 \times 10^{-2}$ & $1.0 \times 10^{-2}$ & -0.09 & IAEA (1982); NCRP (1991) \\
\hline $\mathrm{Te}$ & 1.3 & $6.0 \times 10^{-1}$ & -0.54 & IAEA (1982) \\
\hline I & $2.0 \times 10^{-2}$ & NC & NC & $\begin{array}{l}\text { IAEA (1982); NCRP }(1991) ; \mathrm{Ng} \\
\text { et al. (1982a), NRC (1977) }\end{array}$ \\
\hline $\mathrm{Xe}$ & 0 & $\mathrm{NC}$ & NC & NCRP (1991) \\
\hline Cs & $2.0 \times 10^{-3}$ & $4.0 \times 10^{-2}$ & 19 & NCRP (1991) \\
\hline $\mathrm{Ba}$ & $5.0 \times 10^{-3}$ & NC & $\mathrm{NC}$ & $\begin{array}{l}\text { IAEA (1982); Ng et al. (1982a); } \\
\text { NRC (1977) }\end{array}$ \\
\hline
\end{tabular}


TABLE 9 (Cont.)

\begin{tabular}{|c|c|c|c|c|}
\hline Element & $\begin{array}{c}\text { Current } \\
\text { Default Value }\end{array}$ & $\begin{array}{l}\text { Suggested } \\
\text { Value }\end{array}$ & Change $^{a}$ & $\begin{array}{l}\text { Radiological Assessment } \\
\text { Model Source }\end{array}$ \\
\hline La & $2.5 \times 10^{-3}$ & NC & NC & $\mathrm{Ng}$ et al. (1982a); NRC (1977) \\
\hline $\mathrm{Ce}$ & $5.0 \times 10^{-4}$ & $2.0 \times 10^{-3}$ & 3.0 & IAEA (1982); NCRP (1991) \\
\hline $\mathrm{Pr}$ & $2.5 \times 10^{-3}$ & $\mathrm{NC}$ & NC & $\mathrm{Ng}$ et al. (1982a); NRC (1977) \\
\hline $\mathrm{Nd}$ & $2.4 \times 10^{-3}$ & NC & NC & $\mathrm{Ng}$ et al. (1982a); NRC (1977) \\
\hline $\mathrm{Pm}$ & $2.5 \times 10^{-3}$ & NC & NC & \\
\hline Sm & $2.5 \times 10^{-3}$ & NC & NC & \\
\hline Eu & $2.5 \times 10^{-3}$ & NC & NC & \\
\hline Gd & $2.5 \times 10^{-3}$ & NC & NC & \\
\hline $\mathrm{Tb}$ & $2.6 \times 10^{-3}$ & NC & NC & \\
\hline Ho & $2.6 \times 10^{-3}$ & $\mathrm{NC}$ & NC & \\
\hline W & $1.8 \times 10^{-2}$ & NC & NC & \\
\hline Ir & $9.9 \times 10^{-4}$ & $3.0 \times 10^{-2}$ & 29 & NCRP (1991) \\
\hline $\mathrm{Hg}$ & $3.8 \times 10^{-1}$ & NC & NC & \\
\hline $\mathrm{Pb}$ & $6.8 \times 10^{-2}$ & $1.0 \times 10^{-2}$ & -0.85 & IAEA (1982) \\
\hline $\mathrm{Bi}$ & $1.5 \times 10^{-1}$ & $1.0 \times 10^{-1}$ & -0.33 & IAEA (1982); NCRP (1991) \\
\hline Po & $9.0 \times 10^{-3}$ & $1.0 \times 10^{-3}$ & -0.89 & NCRP (1991) \\
\hline Rn & 0 & NC & NC & NCRP (1991) \\
\hline $\mathrm{Ra}$ & $1.4 \times 10^{-3}$ & $4.0 \times 10^{-2}$ & 28 & IAEA (1982); NCRP (1991) \\
\hline Ac & $2.5 \times 10^{-3}$ & NC & NC & \\
\hline Th & $4.2 \times 10^{-3}$ & $1.0 \times 10^{-3}$ & -0.76 & NCRP (1991) \\
\hline $\mathrm{Pa}$ & $2.5 \times 10^{-3}$ & $1.0 \times 10^{-2}$ & 3.0 & NCRP (1991) \\
\hline $\mathrm{U}$ & $2.5 \times 10^{-3}$ & NC & NC & \\
\hline $\mathrm{Np}$ & $2.5 \times 10^{-3}$ & $2.0 \times 10^{-2}$ & 7 & NCRP (1991) \\
\hline $\mathrm{Pu}$ & $2.5 \times 10^{-4}$ & $1.0 \times 10^{-3}$ & 3 & NCRP (1991) \\
\hline Am & $2.5 \times 10^{-4}$ & $1.0 \times 10^{-3}$ & 3 & NCRP (1991) \\
\hline $\mathrm{Cm}$ & $2.5 \times 10^{-3}$ & $1.0 \times 10^{-3}$ & -0.60 & NCRP (1991) \\
\hline Cf & $2.5 \times 10^{-3}$ & $1.0 \times 10^{-3}$ & -0.60 & NCRP (1991) \\
\hline
\end{tabular}

a Change $=($ suggested value - default value $) /($ default value $)$.

b Not calculated.

c No change. 
TABLE 10 Suggested RESRAD Default Values for Specific Plant Foods (k=1, 2, and 3; for root vegetables, fruit, and grain; leafy vegetables; and forage plants, respectively) (pCi/kg dry weight per $\mathrm{pCi} / \mathrm{kg} \mathrm{dry} \mathrm{soil)}{ }^{\mathrm{a}}$

\begin{tabular}{|c|c|c|c|c|c|c|}
\hline Element & $k=1$ & $\begin{array}{c}\text { Radiological } \\
\text { Assessment } \\
\text { Model Source }\end{array}$ & $k=2$ & $\begin{array}{c}\text { Radiological } \\
\text { Assessment } \\
\text { Model Source }\end{array}$ & $k=3$ & $\begin{array}{c}\text { Radiological } \\
\text { Assessment } \\
\text { Model Source }\end{array}$ \\
\hline $\mathrm{H}$ & 0.0 & b & 0.0 & b & 1 & $N A^{j}$ \\
\hline $\mathrm{Be}$ & $1.5 \times 10^{-3}$ & $c ; d$ & $1.0 \times 10^{-2}$ & $c ; d$ & $1.0 \times 10^{-1}$ & $\mathrm{~g}$ \\
\hline C & $7.0 \times 10^{-1}$ & c & $7.0 \times 10^{-1}$ & c & - & NA \\
\hline $\mathbf{N}$ & 7.5 & b & $3.0 \times 10$ & c; d & $2.0 \times 10$ & g \\
\hline $\mathbf{F}$ & $6.0 \times 10^{-3}$ & $c ; d$ & $6.0 \times 10^{-2}$ & c; d & $1.0 \times 10^{-1}$ & $\mathrm{~g}$ \\
\hline $\mathrm{Na}$ & $5.5 \times 10^{-2}$ & $c ; d$ & $7.6 \times 10^{-2}$ & $c ; d$ & $2.0 \times 10^{-1}$ & $\mathrm{~g} ; \mathrm{h}$ \\
\hline $\mathrm{P}$ & 3.5 & $c ; d$ & 3.5 & $c ; d$ & 3 & $\mathrm{~g} ; \mathrm{h}$ \\
\hline $\mathrm{Cl}$ & $7.0 \times 10$ & $c ; d$ & $7.0 \times 10$ & $c ; d$ & $1.0 \times 10^{2}$ & g \\
\hline $\mathrm{Ar}$ & 0.0 & $\mathrm{~b}$ & 0.0 & b & 0 & g \\
\hline $\mathrm{K}$ & $5.5 \times 10^{-1}$ & c; d & 1.0 & $c ; d$ & 3 & g \\
\hline $\mathrm{Ca}$ & $3.5 \times 10^{-1}$ & $c ; d$ & 3.5 & $c ; d$ & 5 & $\mathrm{~g}$ \\
\hline $\mathrm{Sc}$ & $1.0 \times 10^{-3}$ & $c ; d$ & $6.0 \times 10^{-3}$ & c; d & $1.0 \times 10^{-1}$ & g \\
\hline $\mathrm{Cr}$ & $1.5 \times 10^{-2}$ & e & $7.5 \times 10^{-3}$ & $c ; d$ & $1.0 \times 10^{-1}$ & g \\
\hline $\mathrm{Mn}$ & $1.6 \times 10^{-1}$ & c & $5.6 \times 10^{-1}$ & c & $9.2 \times 10^{-1}$ & $\mathrm{f}$ \\
\hline $\mathrm{Fe}$ & $1.0 \times 10^{-3}$ & $c ; d$ & $4.0 \times 10^{-3}$ & $c ; d$ & $3.0 \times 10^{-3}$ & $e ; h$ \\
\hline Co & $1.7 \times 10^{-2}$ & c & $8.1 \times 10^{-2}$ & c & $4.0 \times 10^{-1}$ & $\mathrm{~h}$ \\
\hline $\mathrm{Ni}$ & $6.0 \times 10^{-2}$ & $c ; d$ & $2.8 \times 10^{-1}$ & c & $1.1 \times 10^{-1}$ & $\mathrm{e}$ \\
\hline $\mathrm{Cu}$ & $2.5 \times 10^{-1}$ & c; d & $4.0 \times 10^{-1}$ & $c ; d$ & $8.0 \times 10^{-1}$ & g \\
\hline $\mathrm{Zn}$ & $9.3 \times 10^{-1}$ & c; d & 1.5 & d & $5.0 \times 10^{-1}$ & $\mathrm{~h}$ \\
\hline As & $6.0 \times 10^{-3}$ & $c ; d$ & $4.0 \times 10^{-2}$ & $c ; d$ & $2.0 \times 10^{-1}$ & g \\
\hline $\mathrm{Se}$ & $2.5 \times 10^{-2}$ & c & $2.5 \times 10^{-2}$ & $c ; d$ & $5.0 \times 10^{-1}$ & $\mathrm{~g}$ \\
\hline $\mathrm{Br}$ & 1.5 & $c ; d$ & 1.5 & c; d & 2 & $\mathbf{g}$ \\
\hline $\mathrm{Kr}$ & 0.0 & b & 0.0 & b & 0 & g \\
\hline $\mathrm{Rb}$ & $7.0 \times 10^{-2}$ & $c ; d$ & $1.5 \times 10^{-1}$ & $c ; d$ & 2 & $\mathrm{~g}$ \\
\hline $\mathrm{Sr}$ & $3.7 \times 10^{-1}$ & c & 1.6 & c & 2 & 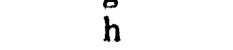 \\
\hline$Y$ & $6.0 \times 10^{-3}$ & $c ; d$ & $1.5 \times 10^{-2}$ & $c ; d$ & $1.0 \times 10^{-1}$ & g \\
\hline $\mathrm{Zr}$ & $1.8 \times 10^{-3}$ & e & $2.0 \times 10^{-3}$ & c; d & $1.0 \times 10^{-1}$ & $\mathrm{~g}$ \\
\hline $\mathrm{Nb}$ & $5.0 \times 10^{-3}$ & $\mathrm{c} ; \mathrm{d}$ & $2.0 \times 10^{-2}$ & $c ; d$ & $1.0 \times 10^{-1}$ & g \\
\hline Mo & $6.0 \times 10^{-2}$ & $c ; d$ & $2.5 \times 10^{-1}$ & c; d & $4.0 \times 10^{-1}$ & $\mathrm{~g}$ \\
\hline $\mathrm{Tc}$ & 1.5 & $d$ & $4.0 \times 10$ & b & $4.0 \times 10$ & g \\
\hline Ru & $1.5 \times 10^{-2}$ & c & $2.0 \times 10^{-1}$ & $\tilde{b}$ & $2.0 \times 10^{-1}$ & g \\
\hline $\mathrm{Rh}$ & $4.0 \times 10^{-2}$ & $c ; d$ & $1.5 \times 10^{-1}$ & c; d & $2.0 \times 10^{-1}$ & g \\
\hline $\mathrm{Pd}$ & $4.0 \times 10^{.2}$ & c; d & $1.5 \times 10^{-1}$ & c; d & $5.0 \times 10^{-1}$ & g \\
\hline $\mathrm{Ag}$ & $1.0 \times 10^{-1}$ & $d$ & $4.0 \times 10^{-1}$ & d & $1.0 \times 10^{-1}$ & $\mathrm{~g}$ \\
\hline $\mathrm{Cd}$ & $1.5 \times 10^{-1}$ & $c ; d$ & $5.5 \times 10^{-1}$ & $c ; d$ & 1 & $\mathrm{~g}$ \\
\hline Sn & $6.0 \times 10^{-3}$ & $c ; d$ & $3.0 \times 10^{-2}$ & c; d & 1 & $\mathrm{~g}$ \\
\hline $\mathrm{Sb}$ & $3.0 \times 10^{-2}$ & d & $5.0 \times 10^{-2}$ & b & $1.0 \times 10^{-1}$ & g \\
\hline $\mathrm{Te}$ & $4.0 \times 10^{-3}$ & $c ; d$ & $2.5 \times 10^{-2}$ & $c ; d$ & $4.0 \times 10$ & $\mathrm{~g}$ \\
\hline I & $5.0 \times 10^{-2}$ & c; d & $1.5 \times 10^{-1}$ & $d$ & $1.7 \times 10^{-1}$ & e \\
\hline $\mathrm{Xe}$ & 0.0 & $\mathrm{~b}$ & 0.0 & b & 0 & g \\
\hline Cs & $9.8 \times 10^{-2}$ & c & $1.3 \times 10^{-1}$ & c & $2.0 \times 10^{-1}$ & g \\
\hline $\mathrm{Ba}$ & $1.5 \times 10^{-2}$ & $c ; d$ & $1.5 \times 10^{-1}$ & $c ; d$ & $1.0 \times 10^{-1}$ & $\mathrm{~g}$ \\
\hline La & $6.4 \times 10^{-4}$ & c & $1.0 \times 10^{-2}$ & c; d & $1.0 \times 10^{-1}$ & g \\
\hline $\mathrm{Ce}$ & $4.0 \times 10^{-3}$ & $c ; d$ & $1.0 \times 10^{-2}$ & $c ; d$ & $1.0 \times 10^{-1}$ & $\mathrm{~g}$ \\
\hline
\end{tabular}


TABLE 10 (Cont.)

\begin{tabular}{|c|c|c|c|c|c|c|}
\hline Element & $k=1$ & $\begin{array}{c}\text { Radiological } \\
\text { Assessment } \\
\text { Model Source }\end{array}$ & $k=2$ & $\begin{array}{c}\text { Radiological } \\
\text { Assessment } \\
\text { Model Source }\end{array}$ & $k=3$ & $\begin{array}{c}\text { Radiological } \\
\text { Assessment } \\
\text { Model Source }\end{array}$ \\
\hline $\mathrm{Pr}$ & $4.0 \times 10^{-3}$ & $c ; d$ & $1.0 \times 10^{-2}$ & $b ; c ; d$ & $1.0 \times 10^{-1}$ & g \\
\hline Nd & $4.0 \times 10^{-3}$ & $c ; d$ & $1.0 \times 10^{-2}$ & $b ; c ; d$ & $1.0 \times 10^{-1}$ & g \\
\hline $\mathrm{Pm}$ & $4.0 \times 10^{-3}$ & c; $d$ & $1.0 \times 10^{-2}$ & b; c; d & $1.0 \times 10^{-1}$ & $\mathrm{~g}$ \\
\hline $\mathrm{Sm}$ & $4.0 \times 10^{-3}$ & c; d & $1.0 \times 10^{-2}$ & $b ; c ; d$ & $1.0 \times 10^{-1}$ & g \\
\hline $\mathbf{E u}$ & $4.0 \times 10^{-3}$ & c; d & $1.0 \times 10^{-2}$ & $b ; c ; d$ & $1.0 \times 10^{-1}$ & g \\
\hline $\mathrm{Gd}$ & $4.0 \times 10^{-3}$ & c; d & $1.0 \times 10^{-2}$ & c; d & $1.0 \times 10^{-1}$ & g \\
\hline $\mathrm{Tb}$ & $4.0 \times 10^{-3}$ & c; d & $1.0 \times 10^{-2}$ & $c ; d$ & $1.0 \times 10^{-1}$ & B \\
\hline Ho & $4.0 \times 10^{-3}$ & c; $d$ & $1.0 \times 10^{-2}$ & $b ; c ; d$ & $1.0 \times 10^{.1}$ & g \\
\hline W & $1.0 \times 10^{-2}$ & c; $d$ & $4.5 \times 10^{.2}$ & c; d & 3 & g \\
\hline Ir & $1.5 \times 10^{-2}$ & $c ; d$ & $6.5 \times 10^{-2}$ & c; d & $2.0 \times 10^{-1}$ & g \\
\hline $\mathrm{Hg}$ & $2.0 \times 10^{-1}$ & $c ; d$ & $9.0 \times 10^{-1}$ & $c ; d$ & 1 & B \\
\hline $\mathrm{Pb}$ & $5.6 \times 10^{-3}$ & c & $4.5 \times 10^{-2}$ & $d$ & $1.0 \times 10^{-1}$ & g \\
\hline $\mathrm{Bi}$ & $5.0 \times 10^{-3}$ & $c ; d$ & $3.5 \times 10^{-2}$ & c; $d$ & $5.0 \times 10^{-1}$ & $\mathrm{~g} ; \mathrm{h}$ \\
\hline Po & $3.3 \times 10^{-4}$ & c & $2.5 \times 10^{-3}$ & c; d & $1.0 \times 10^{-1}$ & $\mathbf{g}$ \\
\hline$R n$ & 0.0 & b & 0.0 & b & 0 & g \\
\hline $\mathrm{Ra}$ & $3.5 \times 10^{-3}$ & c & $7.5 \times 10^{-2}$ & c & $2.0 \times 10^{-1}$ & $g ; h$ \\
\hline $\mathrm{Ac}$ & $3.5 \times 10^{-4}$ & $c_{i} d$ & $3.5 \times 10^{-3}$ & $c ; d$ & $1.0 \times 10^{.1}$ & g \\
\hline Th & $2.1 \times 10^{-4}$ & f & $4.0 \times 10^{-3}$ & b & $9.0 \times 10^{-3}$ & f \\
\hline $\mathrm{Pa}$ & $2.5 \times 10^{-4}$ & c; d & $2.5 \times 10^{-3}$ & $c ; d$ & $1.0 \times 10^{-1}$ & g; h \\
\hline $\mathrm{U}$ & $6.4 \times 10^{-3}$ & c & $8.5 \times 10^{.3}$ & d & $1.0 \times 10^{-1}$ & g \\
\hline $\mathrm{Np}$ & $1.7 \times 10^{-2}$ & $f$ & $1.3 \times 10^{-2}$ & c & $1.0 \times 10^{-1}$ & g; h \\
\hline $\mathrm{Pu}$ & $1.9 \times 10^{-4}$ & $f$ & $3.9 \times 10^{-4}$ & c & $2.7 \times 10^{-4}$ & f \\
\hline Am & $4.1 \times 10^{-4}$ & f & $2.0 \times 10^{-3}$ & b & $4.0 \times 10^{-3}$ & $\mathrm{~h}$ \\
\hline $\mathrm{Cm}$ & $9.2 \times 10^{-4}$ & c & $8.5 \times 10^{-4}$ & d & $4.0 \times 10^{-3}$ & h \\
\hline $\mathrm{Cf}$ & $1.0 \times 10^{-2}$ & c & $1.0 \times 10^{-2}$ & c & $1.0 \times 10^{-1}$ & g \\
\hline
\end{tabular}

ase dry-to-wet weight conversion factors listed in Table 2 to apply these suggested values for RESRAD input.

b Napier et al. (1988).

c Kennedy and Strenge (1992).

d Baes et al. (1984).

- Ng et al. (1982a).

$f$ IAEA (1993),

k NCRP (1991).

h IAEA (1982).

i Data not listed.

j Not applicable. 


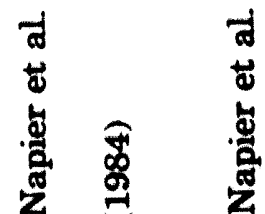

है

$\varepsilon=\frac{2}{2} z$

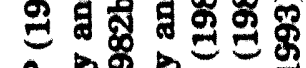

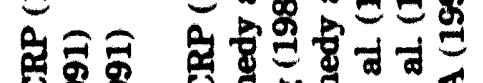
8 8

के ริ

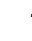

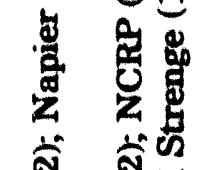

茯 范苛

范

है

节 范

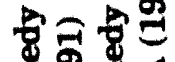

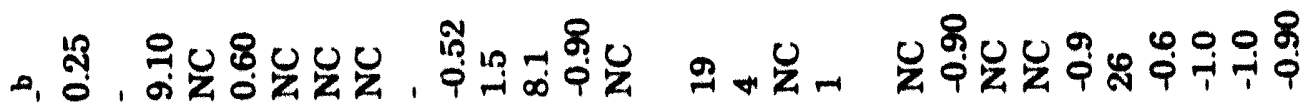
NกN N N

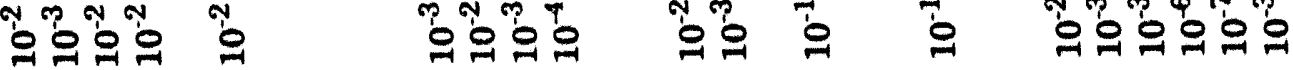
$x \times \times \times x \times x \times x \times x \times x \times x$ भૈ유.

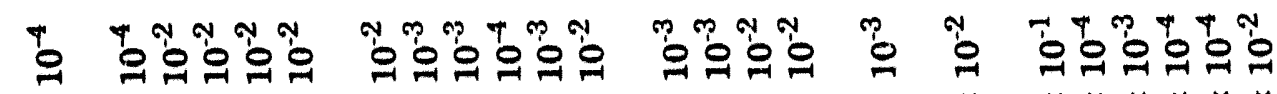
$\times \times \times \times \times \times \times \times \times \times \times \times \times \times \times \times \times \times \times \times \times \times \times x$ ○ 0 o

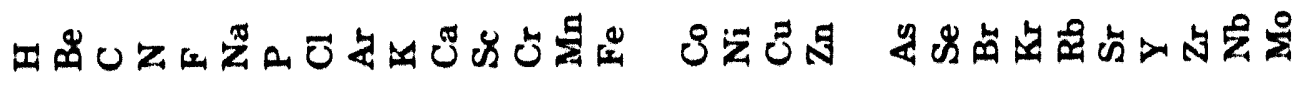




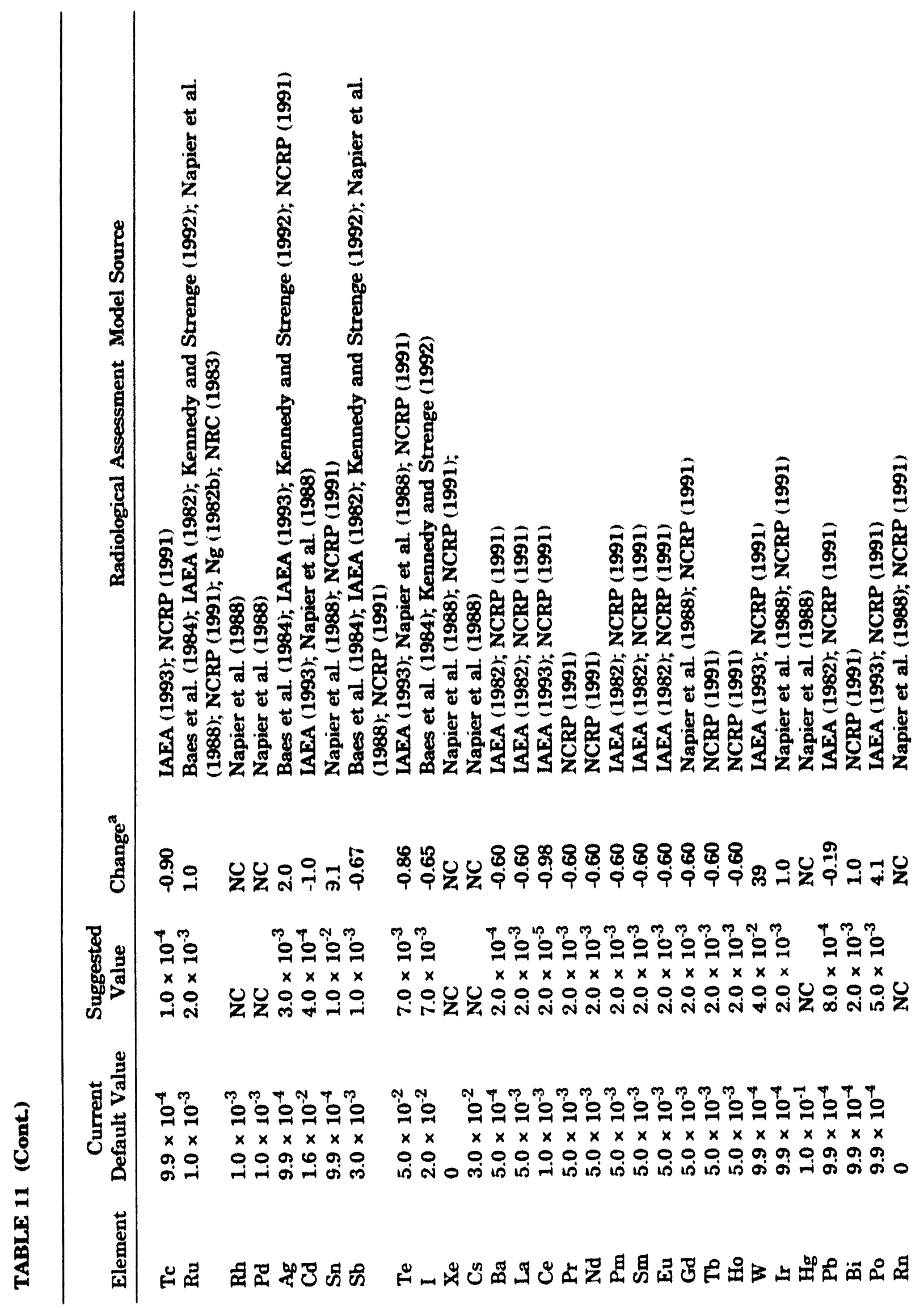




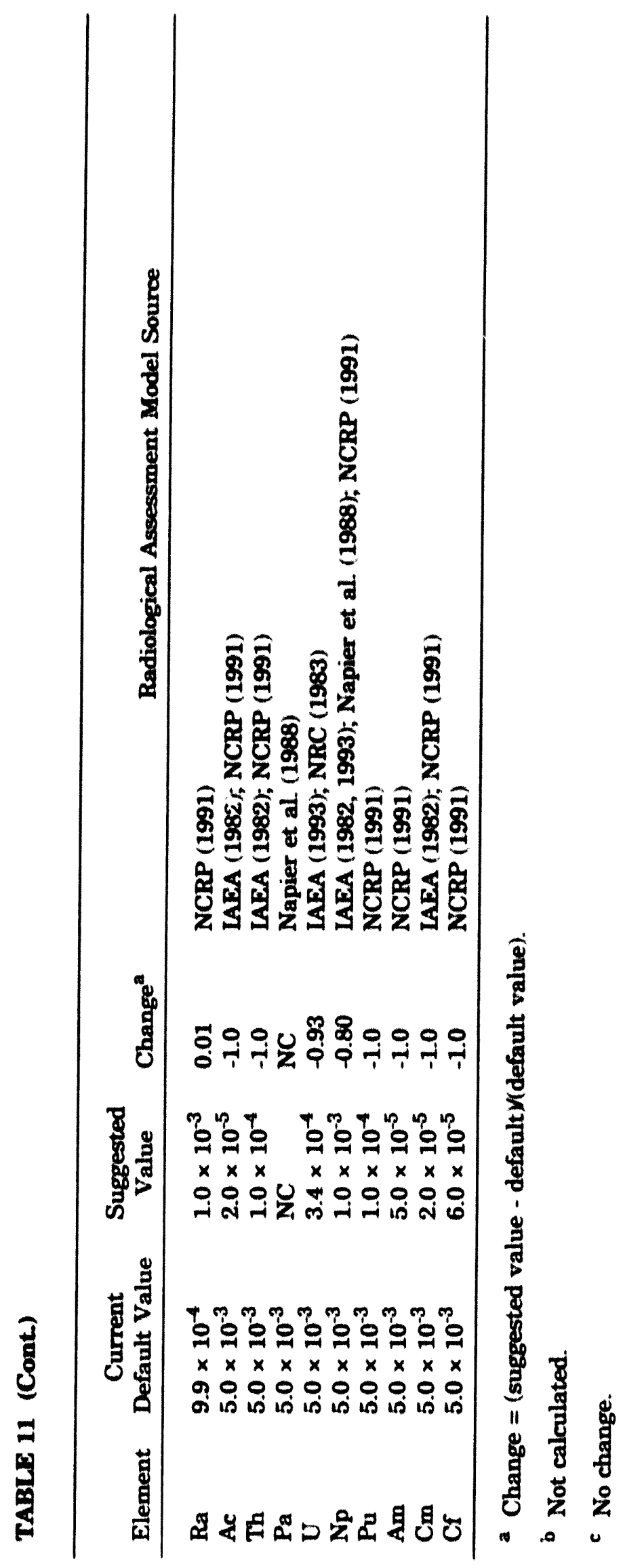




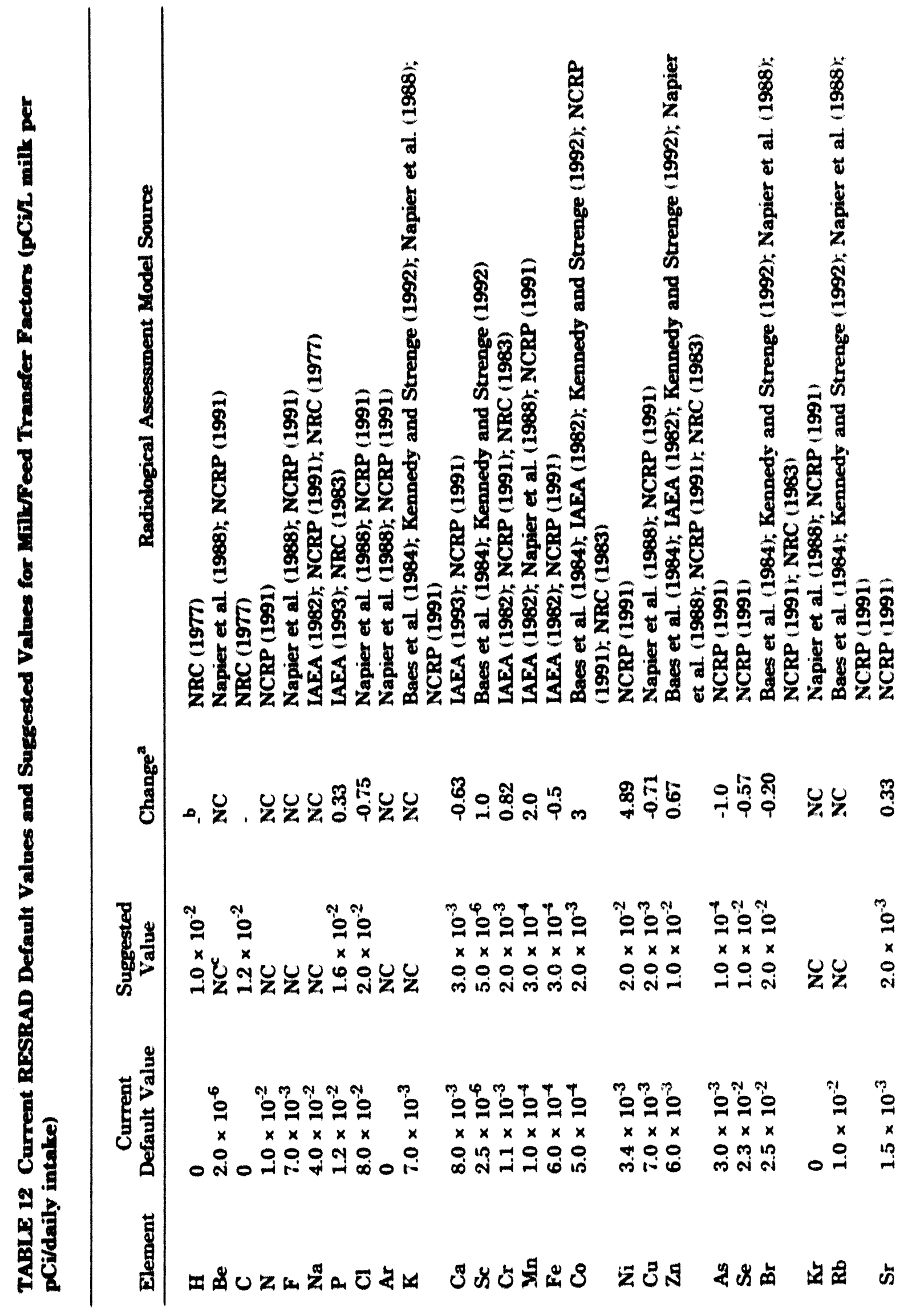




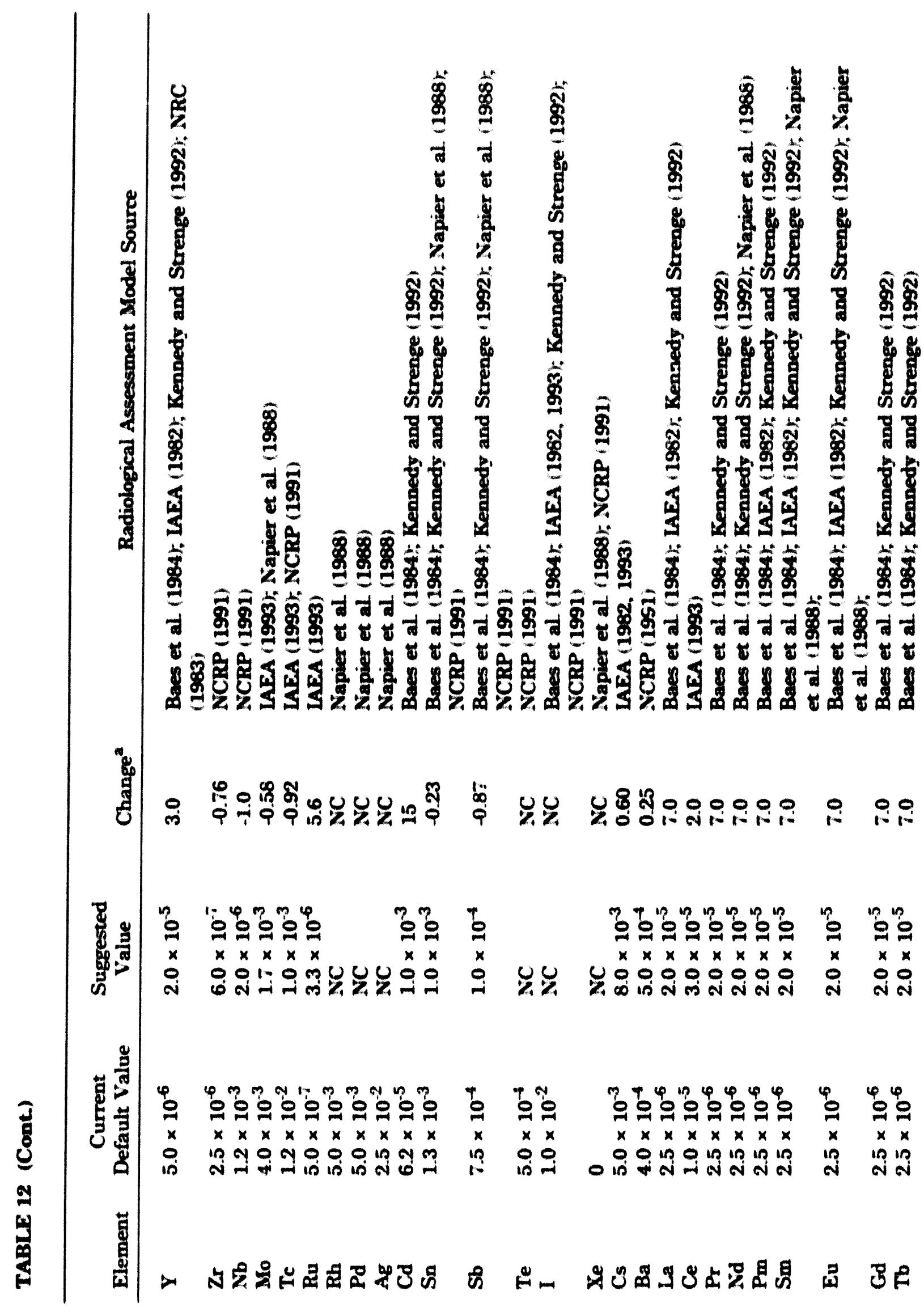




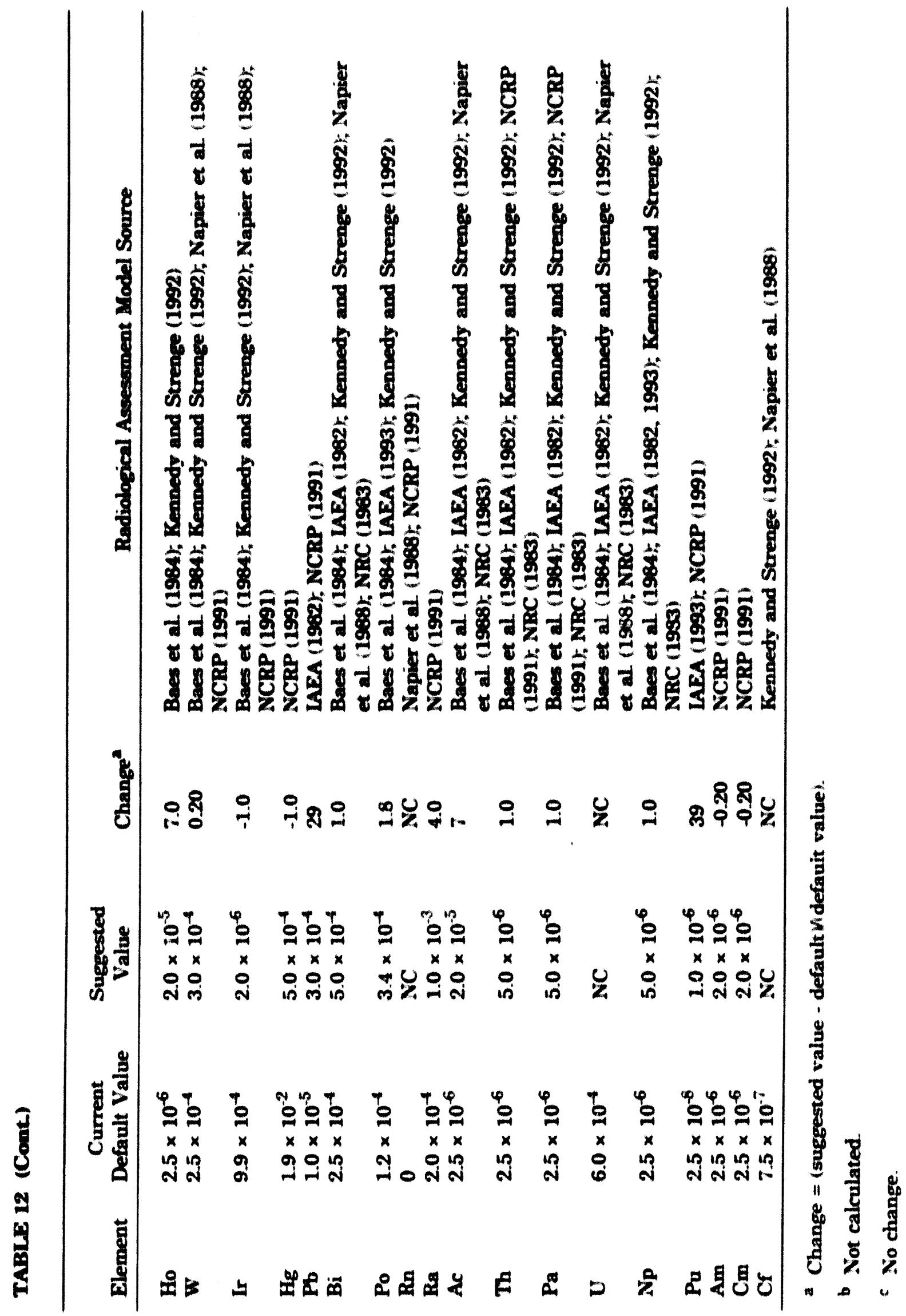




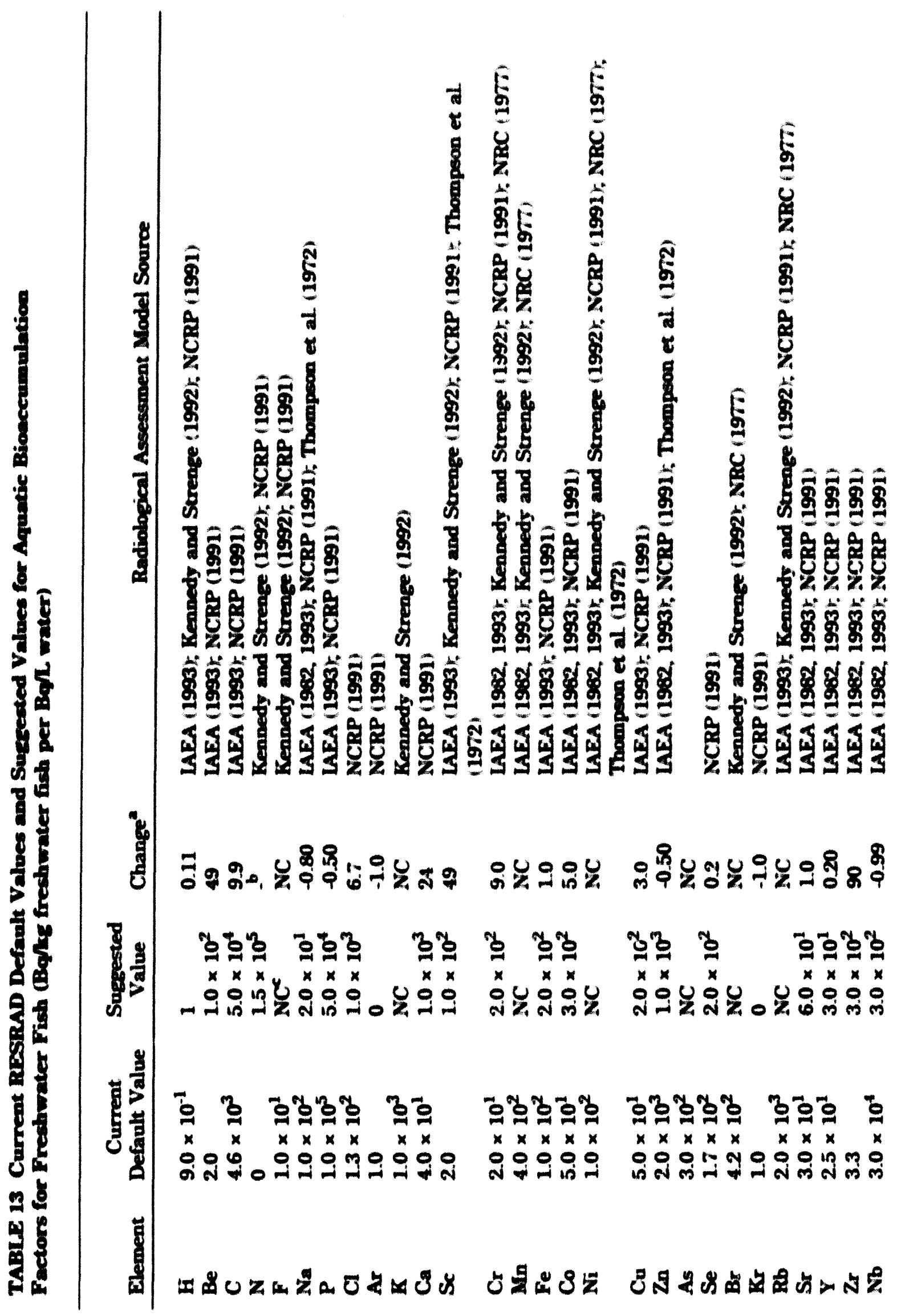




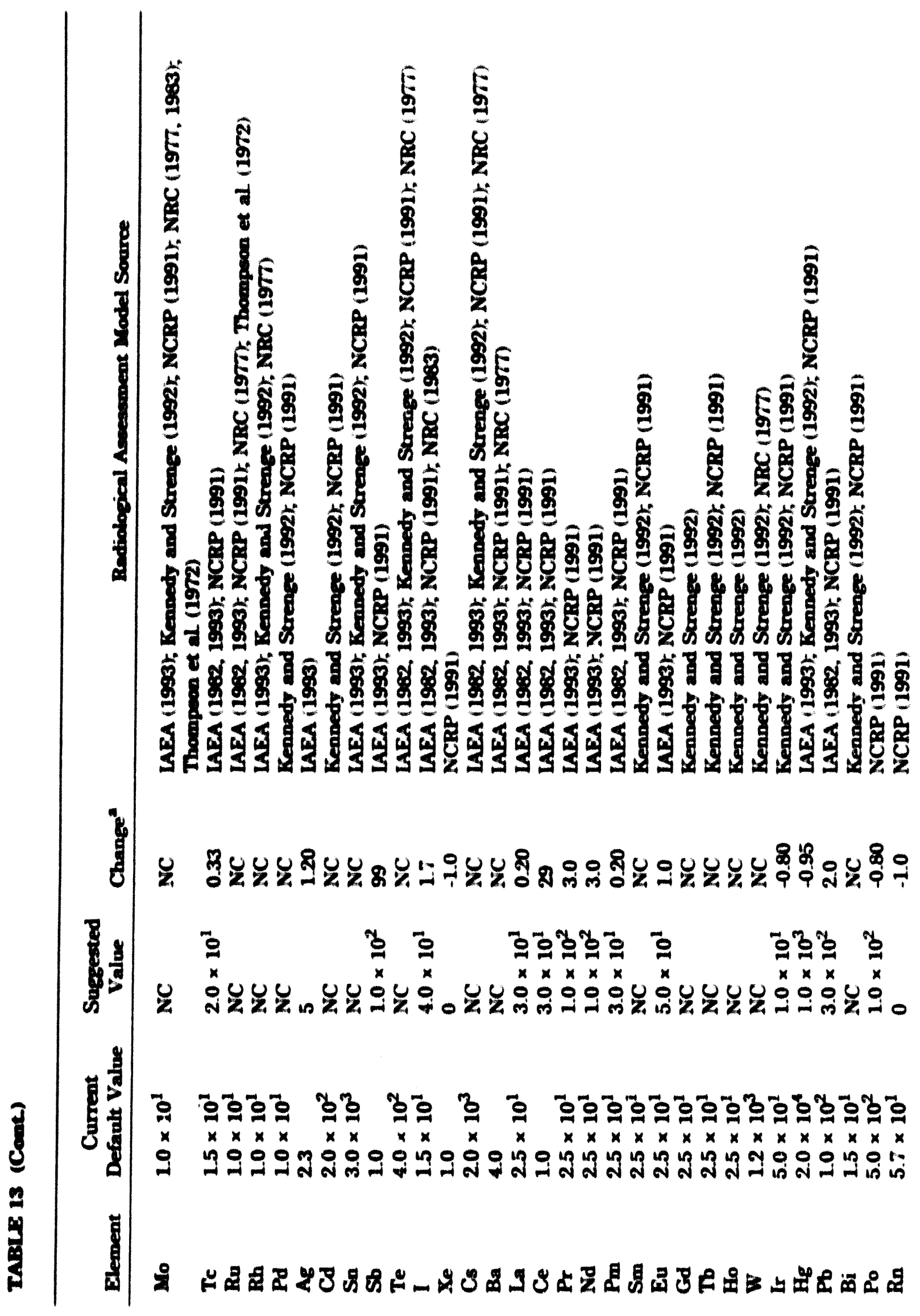




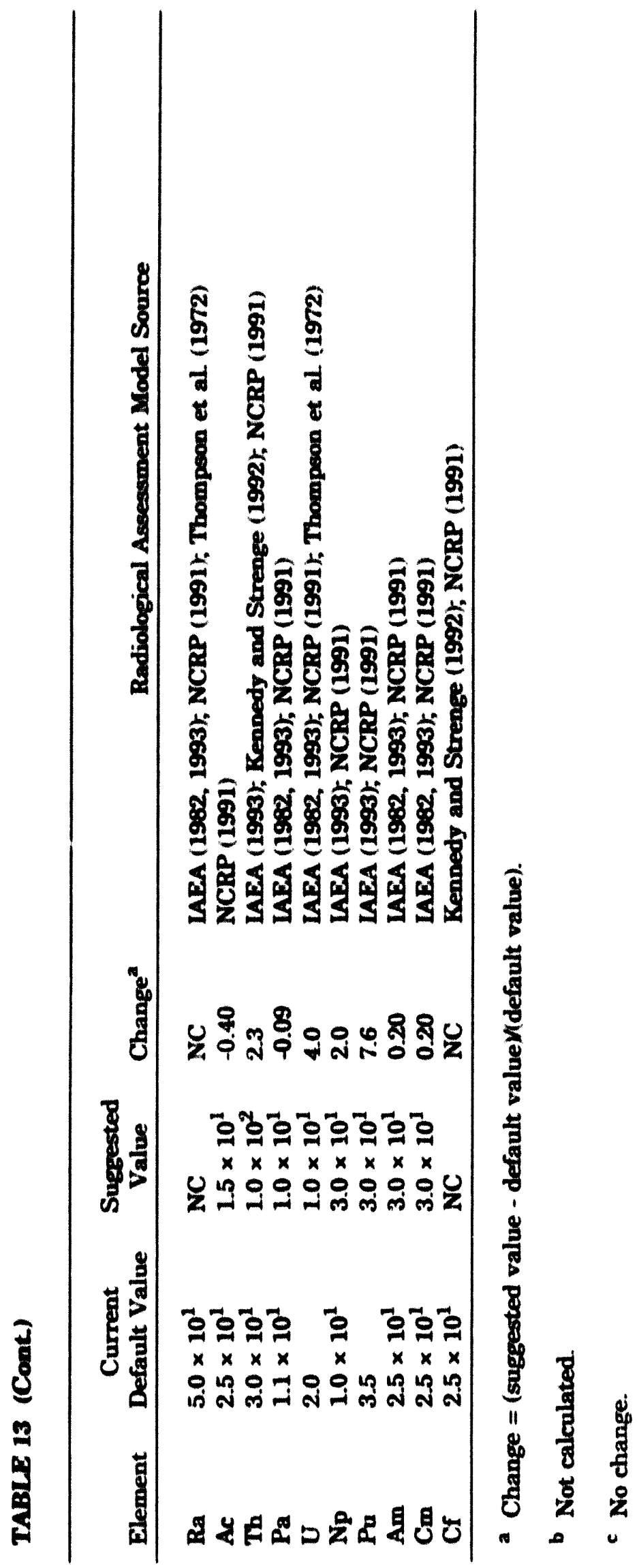




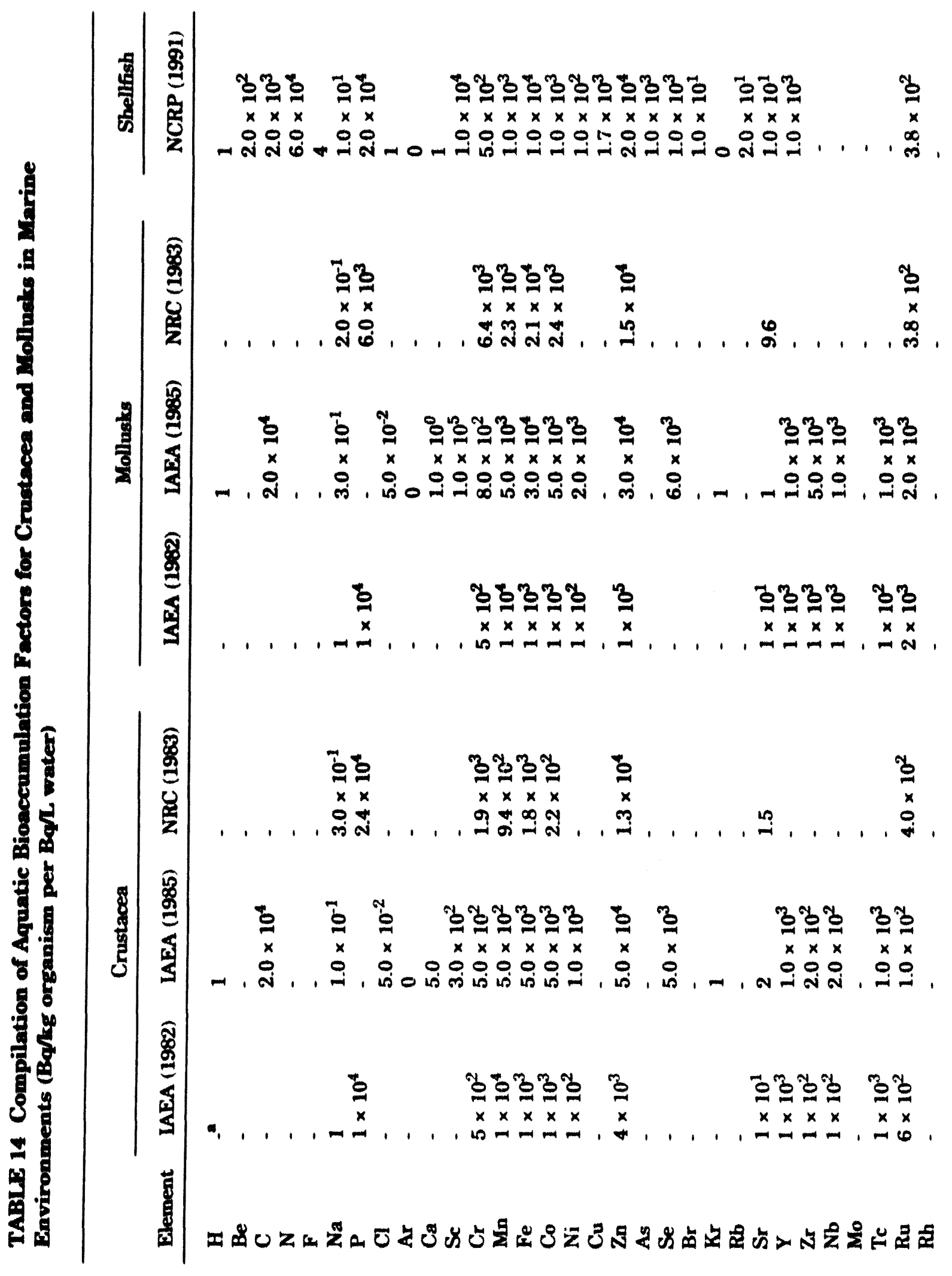




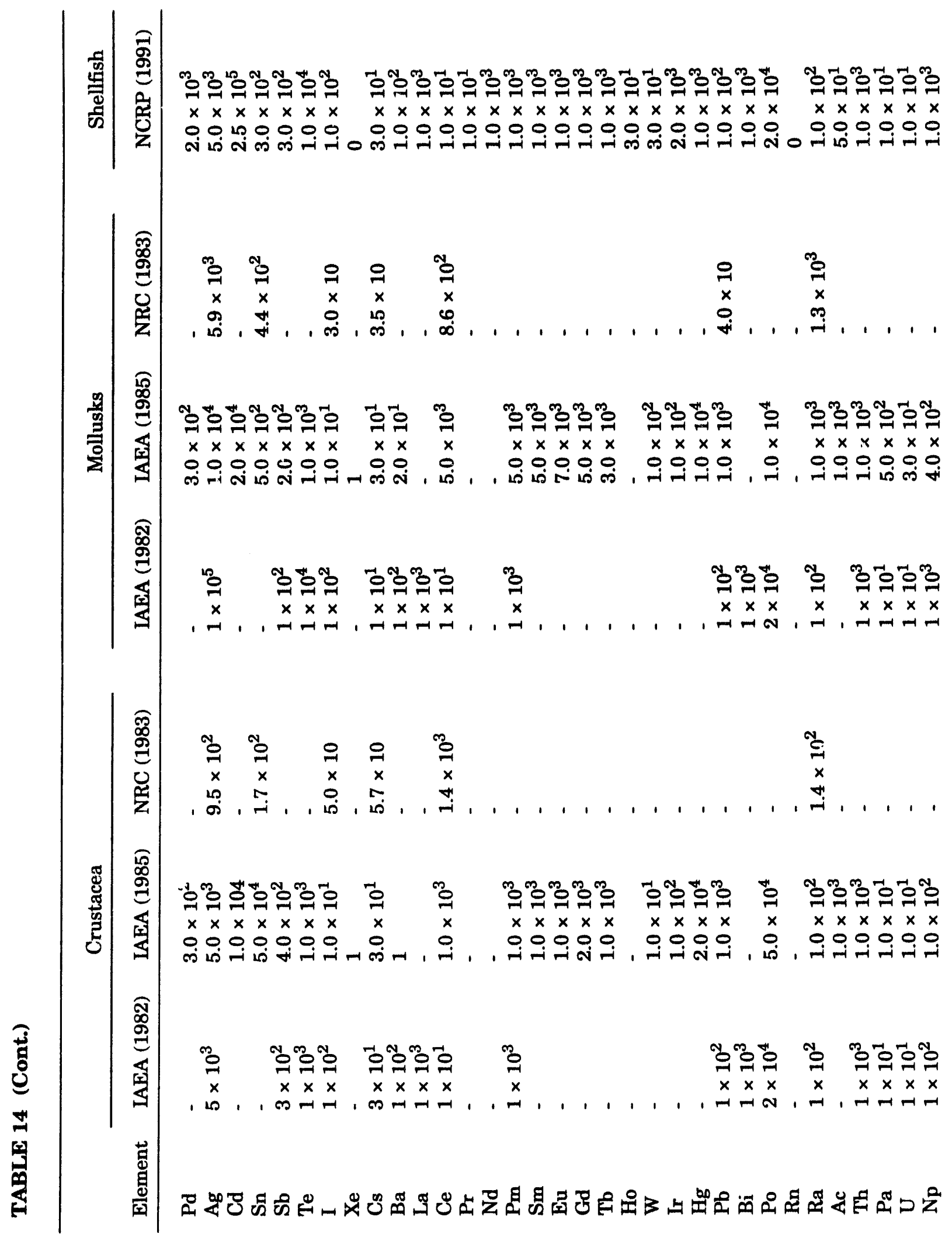




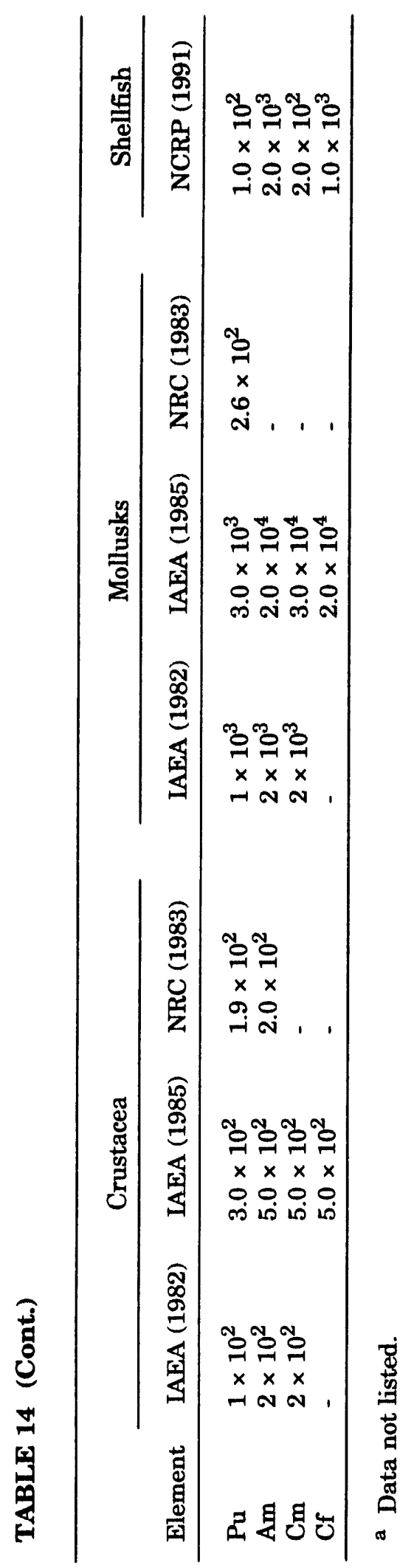




\section{REFERENCES}

Baes, C.F., III, et al., 1984, A Review and Analysis of Parameters for Assessing Transport of Environmentally Released Radionuclides through Agriculture, report ORNL-5786, Oak Ridge National Laboratory, Oak Ridge, Tenn.

Baker, D.A., et al., 1976, Food - An Interactive Code to Calculate Internal Radiation Doses from Contaminated Food Products, report BNWL-SA-5523, Pacific Northwest Laboratory, Richland, Wash.

Beresford, N.A., et al., 1989, "The Effect of Treating Pastures with Bentonite on the Transfer of Cs-137 from Grazed Herbage to Sheep," Journal of Environmental Radiation 9:251-264.

Bishop, G.P., et al., 1989, Review of Literature for Chlorine, Technetium, Iodine and Neptunium, report NSS/R193, Nirex Radioactive Waste Disposal Safety Studies, U.K. Nirex Ltd., Harwell, England.

Blaylock, B.G., 1982, "Radionuclide Data Bases Available for Bioaccumulation Factors for Freshwater Biota," Nuclear Safety 23(4):427-438.

Booth, R.S., et al., 1971, "A Systems Analysis Methodology for Predicting Dose to Man from a Radioactivity Contaminated Terrestrial Environment," Proceedings of the Third National Symposium on Radioecology, report CONF-710501, U.S. Atomic Energy Commission, Oak Ridge, Tenn.

Copeland, R.A., et al., 1973, Trace Element Distributions in Lake Michigan Fish: A Baseline Study with Calculations of Concentration Factors and Equilibrium Radioisotope Distributions, REG Special Report No. 2, University of Michigan, Ann Arbor, Mich.

Coughtrey, P.C., and M.C. Thorne, 1983, Radionuclide Distribution and Transport in Terrestrial and Aquatic Ecosystems, A Critical Review of Data, Vol. 2, A.A. Balkema, Rotterdam.

Coughtrey, P.C., et al., 1983, Radionuclide Distribution and Transport in Terrestrial and Aquatic Ecosystems, Vol. 1, A.A. Balkema, Rotterdam.

Davis, J.J., and R.F. Foster, 1958, "Bioaccumulation of Radioisotopes through Aquatic Food Chains," Ecology 39(3):530-535.

Eisler, R., 1981, Trace Metal Concentrations in Marine Organisms, Pergamon Press, New York.

Fletcher, J.F., and W.L. Dotson, 1971, HERMES - A Digital Computer Code for Estimating Regional Radiological Effects from the Nuclear Power Industry, report HEDL-TME-71-168, Hanford Engineering Development Laboratory, Richland, Wash. 
Friend, A.G., et al., 1965, Behavior of Certain Radionuclides Released into Fresh-Water Environments, Publication 999-RH-13, U.S. Public Health Service, Washington, D.C., June.

Frissel, M. (ed.), 1989, VIth Report of the Working Group Soil-to-Plant Transfer Factors, Report of the Working Group Meeting in Guttannen, Grimselpass, Switzerland, May 24-26, 1968, International Union of Radioecologists, Commission of European Communities.

Garner, R.J., 1972, Transfer of Radioactive Materials from the Terrestrial Environment to Animals and Man, CRC Press, Cleveland, Ohio.

Gilbert, T.L., et ul., 1989, A Manual for Implementing Residual Radioactive Material Guidelines, report ANL/ES-160 (DOE/CH/8901), prepared by Argonne National Laboratory, Energy and Environmental Systems Division, Argonne, Ill., for U.S. Department of Energy, Assistant Secretary for Nuclear Energy, Washington, D.C., June.

Grogan, H.A., 1985, Concentration Ratios for BIOPATH: Selection of the Soil-to-Plant Concentration Ratio Database, report EIR-Bericht Nr. 575, Swiss Federal Institute for Reactor Research, Geneva, Switzerland.

Harvey, R.S., 1964, "Uptake of Radionuclides by Freshwater Algae and Fish," Health Physics 10(4):243-247.

Hoffman, F.O., and C.F. Baes III (eds.), 1979, A Statistical Analysis of Selected Parameters for Predicting Food Chain Transport and Internal Dose of Radionuclides, report NUREG/CR-1004, ORNL/NUREG/TM-282, Oak Ridge National Laboratory, Oak Ridge, Tenn.

Howard, B.J., et al., 1989, "Transfer of Radiocesium from Different Environmental Sources to Ewes and Suckling Lambs," Health Physics 57:579-586.

IAEA (International Atomic Energy Agency), 1975, Impacts of Nuclear Releases into the Aquatic Environment, Proceedings of the IAEA Symposium, Otaniemi, Finland, 30 June-4 July, 1975, IAEA, Vienna, Austria.

IAEA, 1978, The Radiological Basis of the IAEA Revised Definition and Recommendations Concerning High-Level Radioactive Waste Unsuitable for Dumping at Sea, Technical Document 211, Vienna, Austria.

IAEA, 1982, Generic Models and Parameters for Assessing the Environriental Transfer of Radionuclides from Routine Releases; Exposure of Critical Groups, Safety Series No. 57. Vienna, Austria.

IAEA, 1985, Sediment Kds and Concentration Factors for Radionuclides in the Marine Environment, Technical Report Series No. 247, Vienna, Austria.

IAEA, 1993, Unpublished data, Vienna, Austria. 
IUR (International Union of Radioecologists), 1989, Sixth Report of the Working Groups on Soil-to-Plant Transfer Factors, RIVM, Bilthoven, The Netherlands.

Johnson, J.E., et al., 1968, "Metabolism of Radioactive Cesium (Cs-134 and Cs-137) and Potassium of Dairy Cattle as Influenced by High and Lower Forage Diets," Journal of Nutrition 94:282-288.

Johnson, J.E., et al., 1988, "Transfer Coefficients of Selected Radionuclides to Animal Products, 1. Comparison of Milk and Meat from Dairy Cows and Goats," Health Physics 54: 161.166.

Kennedy, W.E., Jr., and D.L. Strange, 1992, Residual Radioactive Contamination from Decommissioning; Volume 1: Technical Basis for Translating Contamination Levels to Annual Total Effective Dose Equivalent, report NUREG/CR-5512, Pacific Northwest Laboratory, Richland, Washington.

Killough, G., and L. McKay, 1976, BIORA2 Bioaccumulation Factors for Freshwater Biota, report ORNL-4992, Oak Ridge National Laboratory, Oak Ridge, Tenn.

Little, C.A., 1979, "The Coefficient for the Transfer of Radionuclides from Annual Intake to Meat, $F_{f}$ " in A Statistical Analysis of Selected Parameters for Predicting Food Chain Transport and Internal Dose of Radionuclides, report ORNL/NUREG/TM-282, Oak Ridge National Laboratory, Oak Ridge, Tenn.

McDowell-Boyer, L.M., et al., 1979, Review and Recommendations of Dose Conversion Factors and Environmental Transport Parameters for ${ }^{210} \mathrm{~Pb}$ and ${ }^{226} \mathrm{Ra}$, report NUREG/CR-0574, U.S. Nuclear Regulatory Commission, Washington, D.C.

McDowell-Boyer, L.M., and C.F. Baes III, 1980, "Terrestrial Food Chain Transport," in Recommendations Concerning Models and Parameters Best Suited to Breeder Reactor Environmental Radiological Assessments, report ORNL-5592, Oak Ridge National Laboratory, Oak Ridge, Tenn.

Moore, R.E., et al., 1979, AIRDOS-EPA: A Computerized Methodology for Estimating Environmental Concentrations and Dose to Man from Airborne Releases of Radionuclides, report ORNL-5532, Oak Ridge National Laboratory, Oak Ridge, Tenn.

Morgan, J.E., and C.J. Beetham, 1990, Review of Literature for Radium, Protactinium, Tin, and Carbon, Nirex Radioactive Waste Disposal Safety Studies, U.K. Nirex Ltd., Harwell, England.

Napier, B.A., et al., 1988, GENII - The Hanford Environmental Radiation Dosimetry Software System; Volume 2: Users' Manual, report PNL-6584, Vol. 2, Pacific Northwest Laboratory, Richland, Wash., Nov.

NAS (National Academy of Sciences-National Research Council), 1971, Radioactivity in the Marine Environments, Washington, D.C. 
NCRP (National Council on Radiation Protection and Measurements), 1991, unpublished data, Washington, D.C.

Newman, G., 1985, Concentration Factors for Stable Metals and Radionuclides in Fish, Mussels, and Crustaceans - A Literature Survey, report SNUPM 1976E, National Swedish Environmental Protection Board, Solna, Sweden.

Ng, Y.C., et al., 1968, Prediction of the Maximum Dosage to Man from the Fallout of Nuclear Devices; IV: Handbook for Estimating the Maximum Internal Dose from Radionuclides Released to the Biosphers, report UCRL-50163, Part IV, Lawrence Livermore National Laboratory, Livermore, Calif.

Ng, Y.C., et al., 1977, Transfer Coefficients for the Prediction of the Dose to Man Via the Forage-Cow-Milk Pathway from Radionuclides Released to the Biosphere, roport UCRL-51939, Lawrence Livermore National Laboratory, Livermore, Calif.

Ng, Y.C., et al., 1979a, "Transfer Coefficients for Terrestrial Food Chain - Their Derivation and Limitations," in Radioaktivitat and Umwelt, Proceedings of the 12th Annual Conference of the Fachverband fur Strahlenchutz, Norderney, West Germany, pp. 455.481.

$\mathrm{Ng}$, Y.C., et al., 1979b, "Transfer Factors for Assessing the Dose from Radionuclides in Agriculture Products," in Biological Implications of Radionuclides Released from Nuclear Industries, Vol. 2, International Atomic Energy Agency, Vienna, Austria.

Ng, Y.C., ot al., 1982a, Soil-to-Plant Concentration Factors for Radiological Assessments, report NUREG/CR-2975, UCID-19463, Lawrence Livermore National Laboratory, Livermore, Calif.

Ng, Y.C., et al., 1982b, Transfer Coefficients for Assessing the Dose from Radionuclides in Meat and Eggs, report NUREG/CR-2976, UCID-19464, Lawrence Livermore National Laboratory, Livermore, Calif.

NRC (U.S. Nuclear Regulatory Commission), 1977, Regulatory Guide 1.109, Rev. 1, Calculation of Annual Doses to Man from Routine Releases of Reactor Effluents for the Purpose of Evaluating Compliance with 10 CFR Part 50, Appendix I, Washington, D.C.

NRC, 1983, Radiological Assessment: A Textbook on Environmental Dose Anaiysis, report NUREG/CR-3332 (ORNL-5968), prepared by Oak Ridge National Laboratory, Oak Ridge, Tenn., for U.S. Nuclear Regulatory Commission, Washinırton, D.C.

NRPB/CEA (National Radiological Board/Commissarıat a l' Energie Atomique), 1979, Methodology for Evaluating the Radiological Consfquences of Radioactive Effluents Released in Normal Operations, report U/386579e, Cornmission of the European Communities, Brussels. 
Onishi, Y., et al., 1981, Critical Review: Radionuclide Transport, Sediment Transport, and Water Quality Mathematical Modeling; and Radionuclide Adsorption/Desorption Mechanisms, report NUREG/CR-1322, PNL-2901, Pacific Northwest Laboratory, Richland, Wash.

Poston, T.M., and D.C. Klopfer, 1986, A Literature Review of the Concentration Ratios of Selected Radionuclides in Freshwater and Marine Fish, report PNL-5484, Pacific Northwest Laboratory, Richland, Wash.

Thompson, S.E., et al., 1972, Concentration Factors of Chemical Elements in Edible Aquatic Organisms, report UCRL-50567, Lawrence Livermore National Laboratory, Livermore, Calif.

Van Bruwaene, R., et al., 1982, "Metabolism of Antimony-124 in Lactating Dairy Cows," Health Physics 43:733-738.

Vnnderploeg, H.A., et al., 1975, Bioaccumulation Factors for Radionuclides in Freshwater Biota, report ORNL-5002, ESD Publication No. 783, Oak Ridge National Laboratory, Oak Ridge, Tenn.

Vinogradov, A.P., 1953, The Elementary Chemical Composition of Marine Organisms, Sears Foundation for Marine Research, Yale University, New Havon, Conn. 

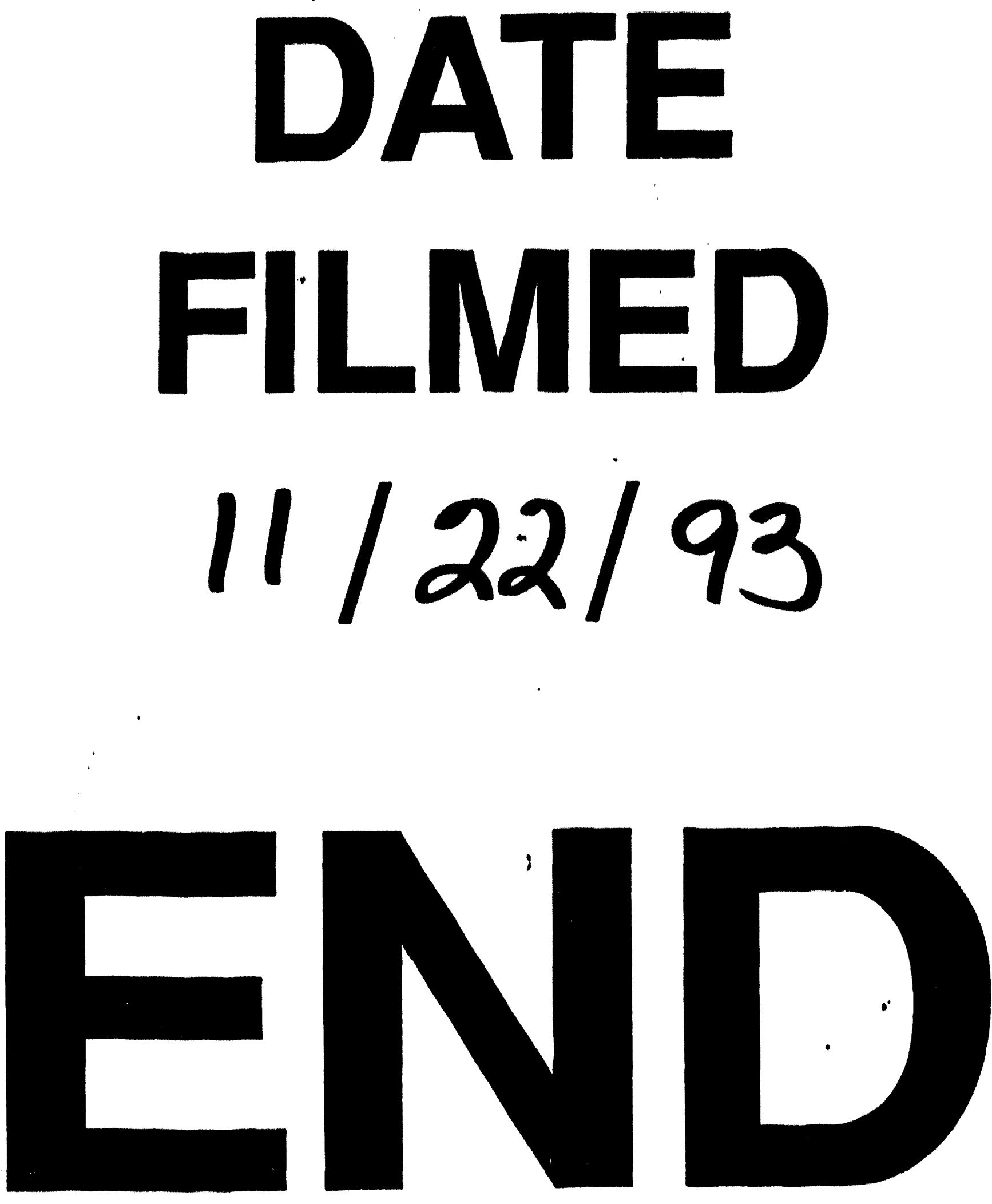
